\title{
Ant And Mite Diversity Drives Toxin Variation In The Little Devil Poison Frog
}

2

4 5

\author{
Jenna R. Mcgugan ${ }^{+1}$, Gary D. Byrd ${ }^{+2}$, Alexandre B. Roland ${ }^{1}$, Stephanie N. Caty ${ }^{1}$, Nisha Kabir ${ }^{3}$,
} Elicio E. Tapia ${ }^{4}$, Sunia A. Trauger ${ }^{2}$, Luis A. Coloma ${ }^{4,5}$, Lauren A. O'Connell ${ }^{1 *}$

1 Center for Systems Biology, Harvard University, Cambridge, MA 02138, USA 2 Small Molecule Mass Spectrometry Facility, Harvard University, Cambridge, MA 02138, USA 3 Cambridge Rindge and Latin High School, Cambridge, MA 02138, USA 4 Centro Jambatu de Investigación y Conservación de Anfibios, Fundación Otonga, Geovanni Farina 566 y Baltra, San Rafael, Quito, Ecuador 5 Ikiam, Universidad Regional Amazónica, Km 7 vía Muyuna, Tena, Ecuador

+ These authors contributed equally to this work

* Corresponding author:

Email: aloconnell@fas.harvard.edu

Telephone: 617-384-7631; Fax: 617.495.2938; 


\section{Abstract}

Poison frogs sequester chemical defenses from arthropod prey, although the details of how arthropod diversity contributes to variation in poison frog toxins remains unclear. We

23 characterized skin alkaloid profiles in the Little Devil frog, Oophaga sylvatica (Dendrobatidae),

24 across three populations in northwestern Ecuador. Using gas chromatography mass

25 spectrometry, we identified histrionicotoxins, 3,5- and 5,8-disubstituted indolizidines,

26 decahydroquinolines, and lehmizidines as the primary alkaloid toxins in these 0 . sylvatica

27 populations. Frog skin alkaloid composition varied along a latitudinal gradient across

28 populations in a principal component analysis. We also characterized diversity in arthropods

29 isolated from frog stomach contents and confirmed O. sylvatica specialize on ants and mites. To

30 test the hypothesis that poison frog toxin diversity reflects species and chemical diversity in

31 arthropod prey, we (1) used liquid chromatography mass spectrometry to chemically profile

consumed ants and mites, and (2) used sequencing of cytochrome oxidase 1 to identify

33 individual prey specimens. We show that chemical profiles of consumed ants and mites cluster

34 by frog population, suggesting different frog populations have access to chemically distinct prey.

35 We identified 45 ants and 9 mites isolated from frog stomachs, finding several undescribed

36 species. Finally, by comparing chemical profiles of frog skin and isolated prey items, we were

37 able to trace the arthropod source of four poison frog alkaloids, including 3,5- and 5,8-

38 disubstituted indolizidines and a lehmizidine alkaloid. Together, our data shows the diversity of

39 alkaloid toxins found in O. sylvatica can be traced to chemical diversity in arthropod prey.

40

41 Key words - Poison frog, alkaloid, toxin, ant, mite, and mass spectrometry. 


\section{INTRODUCTION}

Many organisms have evolved sophisticated chemical defenses to deter predators. Some defended organisms produce their own chemical defenses while others sequester toxins from external sources (Casewell et al. 2013; Olivera et al. 1985; Saporito et al. 2012; Saporito et al. 2009). Toxin sequestration is best understood in invertebrates, where examples of plant to

47 arthropod toxin transfer has been described in great detail (Heckel 2014; Opitz and Müller

48 2009). Compared to invertebrates, far less is known about how vertebrate species acquire

49 chemical defenses from external sources. An example of toxin sequestration among vertebrates

50 is poison frogs, which accumulate alkaloid toxins from arthropod prey (Daly et al. 1994a; Daly et

51 al. 1994b; Hantak et al. 2013; Saporito et al. 2009). Although the dietary basis of poison frog

52 toxicity is well established, the relationship between arthropod prey diversity and frog toxin

53 diversity is not fully understood (Santos et al. 2015; Saporito et al. 2007b; Saporito et al. 2012).

54 Here we characterize the toxins found on the Little Devil frog (Oophaga sylvatica) and their

55 arthropod prey and trace the dietary source of specific alkaloids to the ants and mites they 56 ingest.

57 The term "poison frog" refers to anurans that carry alkaloid toxins in their skin and include 58 several families in South America such as dendrobatids (Dendrobatidae) and bufonids 59 (Melanophryniscus), as well as mantellids (Mantella) from Madagascar, myobatrachids

60 (Pseudophryne) from Australia, and Eleutherodactylids from Cuba (Daly 1995; Daly and Spande

61 1986; Rodríguez et al. 2011). Many poison frogs are diurnal and brightly colored, presumably 62 serving as an aposematic signal to predators (Darst and Cummings 2006; Darst et al. 2005;

63 Santos et al. 2003; Santos et al. 2015). Many of these chemically defended frogs carry small 64 molecule alkaloid toxins in granular glands on their skin (Neuwirth et al. 1979). Decades of work 65 in poison frog chemical ecology has identified over 800 alkaloids organized into over 22 66 structural classes (Daly et al. 2005; Saporito et al. 2012), although the structure of many 
unclassified frog alkaloids remains to be determined. Some of these alkaloids are highly toxic to vertebrates, such as batrachotoxin and pumiliotoxin, while many others like histrionicotoxins and decahydroquinolines are noxious or bitter tasting (Santos et al. 2015). Most of the work on poison frog chemical ecology has focused on the Strawberry poison frog (Oophaga pumilio). Over 250 alkaloids have been identified in O. pumilio with variation both between and within populations (Saporito et al. 2006; Saporito et al. 2007a; Saporito et al. 2010). However, the ecological drivers and genetic contributions to variation in chemical profiles are still not understood. More integrative and comparative work is needed in order to comprehend how environmental and genetic variables contribute to the diverse repertoires of defensive chemicals in poison frogs.

Initial reports on poison frog alkaloid toxins suggested frogs synthesized these chemicals. Once poison frog captive colonies were established, however, researchers determined the frogs had lost their toxicity when fed a diet of fruit flies. These observations led to the dietary hypothesis for poison frog toxicity (Daly et al. 1994a; Daly et al. 1994b), and since then ecological studies have demonstrated that poison frogs ingest mainly ants and mites (Caldwell 1996; Donnelly 1991; Toft 1980), that this dietary specialization correlates with toxicity (Darst et

83 al. 2005), and that the sequestration of alkaloid toxins from arthropod prey has independently 84 evolved at least four times in the Dendrobatidae family (Santos et al. 2003). Presumably, these 85 toxic species have evolved sequestration mechanisms that allow the binding and transport of 86 toxins from the gut to the skin, although this pathway has not yet been identified (Santos et al. 87 2015; Saporito et al. 2012). Nevertheless, as poison frogs sequester their toxins from arthropod 88 prey, it has been proposed that the toxin diversity observed within and between species is 89 reflective of arthropod diversity in the tropics (Saporito et al. 2012; Saporito et al. 2009). This 90 implies that sequestration mechanisms in poison frogs must be broad enough to sequester a 91 range of chemicals that take advantage of local arthropod chemistry. Understanding how poison 
92 frogs acquire toxins and how differences in diet influence toxin variability and the maintenance

93 of aposematism remains a challenge.

Most research efforts to identify the dietary source of frog alkaloids have focused on arthropods collected from leaf litter. Ants have been identified as a source of many poison frog alkaloids including pumiliotoxins, histrionicotoxins, 5,8 and 3,5-disubstituted indolizidines, decahydroquinolines and pyrrolizidines (Heckel 2014; Jones et al. 1999; Saporito et al. 2004).

Despite their small size, mites seem to confer the greatest diversity of alkaloids to poison frogs.

99 Oribatid mites in particular have been explored as the source of many poison frog toxins, 100 including pumiliotoxins and indolizidines (Saporito et al. 2007b; Saporito et al. 2011; Takada et al. 2005). Although there is a clear connection between alkaloid-containing arthropods and poison frog specialization on these ants and mites, little is known about the specific arthropod species poison frogs ingest and the alkaloids these arthropods carry. This is especially the case for mites, whose taxonomy is far understudied compared to ants (Saporito et al. 2015). Although broad leaf litter collections of arthropods and subsequent chemical analyses are useful (Daly et identification from frog stomachs, chemical analyses of arthropod prey items, and how the arthropod chemical diversity corresponds to poison frog toxin diversity are needed as the next step toward causatively linking poison frog skin toxins to their dietary source.

To determine how arthropod diversity contributes to toxin diversity in a poison frog, here we characterize the alkaloid composition and diet of the Little Devil frog (or Diablito frog, Oophaga sylvatica) and trace the dietary source of toxins to ants or mites. We test the hypothesis that 113 ingested ant and mite species differ across frog populations, and that the chemical diversity of 114 ingested prey contributes to corresponding differences in alkaloid variation across frog 115 populations. We first use gas chromatography mass spectrometry (GCMS) to profile the 116 chemical diversity of three Little Devil populations. Then, to test the hypothesis that variation in 
117 poison frog toxin profiles reflects the chemical diversity of arthropod prey, we use liquid

118 chromatography mass spectrometry (LCMS) to chemically profile consumed ants and mites. We

119 also identify prey items isolated from frog stomachs using the DNA barcode cytochrome oxidase

1201 (CO1) (Meusnier et al. 2008). Finally, we compare the chemical profiles of frogs and their prey

121 items in order to identify either ants or mites as the source of specific alkaloids found in different

122 frog populations.

\section{METHODS AND MATERIALS}

\section{Field collection}

Little Devil (Oophaga sylvatica) frogs were collected during the day near the villages of Cristóbal Colón ( $\mathrm{N}=10)$, Simón Bolívar $(\mathrm{N}=10)$ and along the Felfa River $(\mathrm{N}=12)$ near the village Montalvo in the northwestern Esmeraldas province of Ecuador in July 2014. Collections and exportation of specimens were done under permits (001-13 IC-FAU-DNB/MA, CITES 17V/S) issued by the Ministerio de Ambiente de Ecuador. Frogs were individually stored in plastic bags with air and vegetation for 3-8 hours. In the evening the same day of capture, frogs were anesthetized with a topical application of $20 \%$ benzocaine and euthanized. The dorsal skin

133 (from the back of the head but not including the legs) was isolated and stored in $100 \%$ 134 methanol. The stomachs were dissected and their contents were sorted by arthropod type (as genera could not be visually determined) into separate tubes of ants, mites, and other arthropods. Arthropods were stored in $100 \%$ methanol at $4^{\circ} \mathrm{C}$ for a few weeks. To have a non-

137 toxic control group, we also collected five frogs near Otokiki (Province Esmeraldas) and fed 138 them crickets and fruit flies for three months in captivity. The Institutional Animal Care and Use 139 Committee of Harvard University approved all procedures (Protocol 15-02-233). Remaining frog 140 tissues were preserved in $100 \%$ ethanol and deposited in the amphibian collection of Centro 141 Jambatu de Investigación y Conservación de Anfibios in Quito, Ecuador (CJ 3089-3139). In 
order to protect the vulnerable $O$. sylvatica populations that are highly targeted by illegal poaching, specific GPS coordinates of frog collection sites can be obtained from the corresponding author.

\section{Quantification of arthropods in stomach contents}

Each arthropod was individually photographed using a Lumenera Infinity 2 camera mounted on an Olympus dissection microscope (SZ40) and assigned a unique seven digit identification number with the first four digits being the voucher specimen number of the frog from which the arthropod was taken and the last three digits being the number assigned to the arthropod in increasing order from which it was removed from the stomach contents. Ant and mite samples from the stomach contents of 5 frogs from each population were selected for alkaloid analysis using liquid chromatography mass spectrometry (LCMS) based on the largest quantity of mites recovered. These samples for LCMS were pooled by arthropod type (ants, mites or other) into $100 \%$ methanol until alkaloid extraction. The arthropod samples from the remaining frogs were individually placed in vials of $100 \%$ ethanol for later molecular identification by PCR.

Diet was quantified both by quantity of each arthropod type (ants, mites, beetles or "other") and by volume of each arthropod type to account for the wide range of prey size. To determine volume, the photographs of each arthropod were analyzed using Image J (National Institute of Health, Bethesda, MD) to determine their dimensions. Length measurements were taken from the tip of the mandible and extended to the rearmost point of the arthropod. The width measurement was taken at the midpoint of the arthropod and excluded the extra girth added by appendages. If the prey item was fragmented, the measurements were taken from the nearest identifiable body part. The length and width measurements were used to calculate the volume of each prey item. The equation of a prolate sphere was used for the volume calculation of the ant, beetle, and other arthropods: $V=(4 \pi / 3) *($ Length $/ 2) *(\text { Width } / 2)^{\wedge} 2$. The different body shapes among the mites taken from the stomach contents required the use of three different 
formulas to most accurately describe their volume and shape. In addition to the equation for a prolate sphere, the equations of a hemi-cylinder (VHC) and a sphere (VS) were also used based on individual mite shape: $V H C=(4 \pi / 6) *($ Length $/ 2) *(W i d t h / 2)^{\wedge} 2$ and $V S=(4 \pi / 3) *$ $(\text { Diameter } / 2)^{\wedge} 3$.

\section{Isolation of alkaloids}

A set of samples including frog skins, stomach-isolated ants and stomach-isolated mites from five frogs across populations of Felfa, Simón Bolívar, and Cristóbal Colón were used to characterize alkaloid profiles (45 samples in total). Five additional skin samples from captive frogs (described above) were used as a control. The contents of each sample vial (including arthropods and $100 \%$ methanol) were emptied into a sterilized Dounce homogenizer. The empty vial was rinsed with $1 \mathrm{~mL}$ of methanol and added to the homogenizer to ensure the full transfer of all materials. As an internal standard, $25 \mu \mathrm{g}$ of D3-nicotine in methanol (SigmaAldrich, St. Louis, MO) was added to each vial. The sample (either frog skin or arthropods) was ground with the piston ten times in the homogenizer before being transferred to a glass vial. The homogenizer and piston were rinsed with $1 \mathrm{~mL}$ of methanol that was then also added to the glass vial to collect any alkaloid residue. The equipment was cleaned with a triple rinse of methanol before being used to process another sample. A $200 \mu \mathrm{L}$ aliquot of sample was removed for later LCMS analysis. The remainder of the frog skin samples was evaporated to dryness under nitrogen gas, reconstituted in $0.5 \mathrm{~mL}$ of methanol by vortexing. The samples were transferred to a microcentrifuge tube and spun at $12000 \mathrm{rpm}$ for $10 \mathrm{~min}$. A $200 \mu \mathrm{L}$ aliquot of the supernatant was transferred to a $0.3 \mathrm{~mL}$ glass insert in an amber sample vial for later GCMS analysis. All samples were stored at $-20^{\circ} \mathrm{C}$ until GCMS (frog skin only) or LCMS (frog skin, ants, and mites) analyses.

\section{Gas chromatography mass spectrometry (GCMS)}


GCMS analysis was based on a slight modification of the method reported by (Saporito et Agilent 6890N GC (Palo Alto, CA). A J\&W DB5ms $30 \mathrm{~m} \times 0.25 \mathrm{~mm}$ column with a $0.25 \mu \mathrm{m}$ film

194 thickness (Agilent Technologies, Palo Alto, CA) was used for separations. Helium carrier gas 195 was held constant at $1 \mathrm{~mL} / \mathrm{min}$ and split injection (split flow ratio of 12) was used with an injector 196 temperature of $280^{\circ} \mathrm{C}$. A $2 \mu \mathrm{L}$ injection of the concentrated and reconstituted methanol 197 extracted samples were used for GCMS analysis. The column temperature gradient began with 198 a $1 \mathrm{~min}$ hold at $100^{\circ} \mathrm{C}$ then increased at $8^{\circ} \mathrm{C} / \mathrm{min}$ to $280^{\circ} \mathrm{C}$ and was held for $2.5 \mathrm{~min}$. The 199 interface temperature was $280^{\circ} \mathrm{C}$. The mass spectrometer was operated in the $70 \mathrm{eV}$ electron 200 ionization mode and scanned continuously in the range $\mathrm{m} / \mathrm{z} 20-616$ at a rate of $0.4 \mathrm{sec} / \mathrm{scan}$. 201 Each total ion chromatogram was reviewed and alkaloid responses were characterized from 202 their mass spectra and retention times. The extensive database developed by (Daly et al. 2005) 203 was used to tentatively identify the alkaloids by matching major mass spectrum peaks and relative retention times using D3-nicotine as a reference.

\section{Liquid chromatography mass spectrometry (LCMS)}

LCMS analyses were primarily performed on a Bruker maXis Impact Q-TOF system 207 (Billerica, MA) with an Agilent 1290 LC (Palo Alto, CA). Product ion scans of the ant/mite/skin correlation study were performed on an Agilent 6550 Q-TOF (Palo Alto, CA) configured with the same LC system and operated with similar MS parameters. A reversed-phase LC gradient method was developed using a Phenomenex Gemini C18 $3 \mu \mathrm{m} 2.1$ x $100 \mathrm{~mm}$ column

211 (Torrance, CA). Mobile phase A was composed of water with $0.1 \%$ formic acid and mobile 212 phase B was composed of acetonitrile with $0.1 \%$ formic acid. The flow rate was $0.2 \mathrm{~mL} / \mathrm{min}$. The 213 gradient began with $0 \%$ B for one min then increased linearly to $100 \%$ B at 15 min and was held 214 until $18 \mathrm{~min}$. LCMS is much more sensitive than GCMS and a $1 \mu \mathrm{L}$ injection volume of the un215 concentrated arthropod samples and a 20-fold diluted (with methanol) frog skin sample was 
used for LCMS analysis. The Bruker mass spectrometer was tuned for standard mass range analysis and data were continually acquired in the range $\mathrm{m} / \mathrm{z} 50-3000$; each run was recalibrated using a post-run injection of a sodium formate solution. Electrospray positive mode ionization was used with a source drying gas of $10 \mathrm{~L} / \mathrm{min}$ at $200^{\circ} \mathrm{C}$, nebulizer at 30 psi, and capillary set at $4000 \mathrm{~V}$ with an endplate offset of $500 \mathrm{~V}$. For the Agilent Q-TOF, the lon Funnel electrospray positive mode source used drying gas of $14 \mathrm{~L} / \mathrm{min}$ at $200^{\circ} \mathrm{C}$ with nebulizer at 35 psi, a sheath gas flow of $11 \mathrm{~L} / \mathrm{min}$ at $350^{\circ} \mathrm{C}$, capillary set at $3500 \mathrm{~V}$, nozzle voltage of $1000 \mathrm{~V}$, and Fragmentor set at $175 \mathrm{~V}$. Collision energies were set at 15 and $30 \mathrm{eV}$ and data were continually acquired in the range $\mathrm{m} / \mathrm{z}$ 50-1700 using a reference lock mass. Alkaloid responses were identified by retention times and high-resolution mass spectra. Although elemental composition determinations with less than $5 \mathrm{ppm}$ accuracy were possible, and some MS/MS data were acquired, there is no LCMS database for frog alkaloid compounds. The occurrence of numerous alkaloid isomers made tentative identifications by LCMS challenging. Comparisons with GCMS data from frog skin were required for tentative identification of alkaloids given that standards for frog alkaloids are not commercially available.

Arthropod genomic DNA extraction

Ant genomic DNA was isolated using a prepGEM Insect kit (ZyGEM, Hamilton, New sterile plastic pestle before following the manufacturers' instructions. Mite genomic DNA was

236 isolated using a phenol-chloroform extraction based on protocols from (Doyle 1987) and

237 (Navajas et al. 1998) with some modifications. To crush the exoskeleton, each mite was 238 pulverized individually in a microcentrifuge tube filled with $200 \mu \mathrm{L}$ of extraction buffer $(2 \%$ CTAB, $2391.4 \mathrm{M} \mathrm{NaCl}, 0.2 \%$ 2- $\beta$ mercaptoethanol, $20 \mathrm{mM}$ EDTA, $100 \mathrm{mM} \mathrm{TRIS-HCl} \mathrm{pH} \mathrm{8)} \mathrm{with} \mathrm{a} \mathrm{sterile}$ 240 plastic pestle before being incubated for $30 \mathrm{~min}$ at $60^{\circ} \mathrm{C}$. Cold isopropanol was added to 
241 precipitate the DNA. After centrifugation, the DNA pellet was washed with $75 \%$ ethanol before

242 resuspention in water. Purified genomic DNA was stored held at $-20^{\circ} \mathrm{C}$ until PCR.

\section{Molecular identification of stomach contents}

244 To identify mites and ants collected from the stomachs of Oophaga sylvatica, we used PCR

245 to amplify the cytochrome oxidase 1 (CO1) region of genomic DNA, which is often used for 246 arthropod taxonomic barcoding (Meusnier et al. 2008; Smith et al. 2005; Young et al. 2012). For 247 all reactions, we used $2 \mu$ of each primer $(10 \mu \mathrm{M})$ and $25 \mu \mathrm{L}$ of $2 X$ Phusion High-Fidelity PCR

248 Master Mix with GC Buffer (New England Biolabs, Ipswich, MA) in a total reaction volume of 50

$249 \mu \mathrm{L}$. Samples were amplified with either the primers LCO-1490 (5'-

250 GGTCAACAAATCATAAAGATATTGG) and HCO-2198 (5'-

251 TAAACTTCAGGGTGACCAAAAATCA) from (Folmer et al. 1994) or the primers Cl-J-1632 (5'-

252 TGATCAAATTTATAAT) and $\mathrm{Cl}-\mathrm{N}-2191$ (GGTAAAATTAAAATATAAACTTC) from

253 (Kambhampati and Smith 1995). A touchdown PCR program was used as follows: one round of

$25495^{\circ} \mathrm{C}$ for $5 \mathrm{~min} ; 5$ rounds of $95^{\circ} \mathrm{C}$ for $40 \mathrm{sec}, 45^{\circ} \mathrm{C}$ for $40 \mathrm{sec}$ with $-1^{\circ} \mathrm{C}$ per cycle, $72^{\circ} \mathrm{C}$ for $1 \mathrm{~min}$;

25540 rounds of $95^{\circ} \mathrm{C}$ for $40 \mathrm{sec}, 40^{\circ} \mathrm{C}$ for $40 \mathrm{sec}, 72^{\circ} \mathrm{C}$ for $1 \mathrm{~min}$; one round of $72^{\circ} \mathrm{C}$ for $5 \mathrm{~min}$.

256 Successful reactions with one band of the expected size were purified with the E.Z.N.A. Cycle

257 Pure Kit (Omega Bio-Tek, Norcross, GA) and Sanger sequenced by GeneWiz Inc. (Cambridge, 258 MA).

259 We were able to PCR amplify CO1 in 45 out of 137 ant samples and 9 out of 20 mite 260 samples. Nucleotide BLAST of the NCBI Genbank nr database was used to identify the 261 resulting CO1 sequences (Online Resource Tables 1 and 2). For ants and mites, we assigned a 262 family or genus level taxonomic identity based on the results of the BLAST search, where we 263 considered greater than $96 \%$ sequence similarity sufficient to assign species or genera. For less 264 than 95\% similarity, we assigned specimens to a family based on BLAST similarity. For some 265 ant specimens, we were able to identify the species based on the greater wealth of DNA 
barcoding information available for ants as compared to mites. For ants and mites separately, we used the software MEGA 6.0 (Tamura et al. 2013) to align using ClustalW the CO1 sequences from this study with other closely related species retrieved from GenBank. A nearest-neighbor joining tree was then constructed with a bootstrap of 5000 replications. All arthropod CO1 sequences have submitted to GenBank (Accession numbers: ants KU12845397; mites KT947980-8).

\section{Data analysis and statistics} (Daly et al. 2005). Electron ionization mass spectrometry produced spectra of frog skin alkaloids with base peaks that are specific diagnostic ions based on the Daly GCMS database (Daly et al.

276 2005). Seven diagnostic ions were selected from their occurrence in the most abundant 277 alkaloids across several frog populations. These extracted ion chromatograms were overlaid and normalized to the same scale to create a visual overview of major alkaloid distribution in different populations. Individual samples from each population were also processed in the same manner to visually compare individual variation within each frog population (See Online Resource). GCMS alkaloid data were statistically analyzed using an ANOVA and principal component analysis in XCMS software maintained by the Scripps Center for Metabolomics (Tautenhahn et al. 2012). XCMS calculates relative abundance by integrating the area under each ion current response. An ANOVA was run for each feature and a q-value (or Bayesian posterior p-value) was calculated to account for multiple testing (Storey 2003). All raw mass spectrometry data is available at DataDryad (TBD).

We used LCMS for analysis of alkaloids common to frogs and arthropods. For each frog skin, ant, and mite sample, five to seven of the most abundant alkaloids were selected for generation of an extracted ion chromatogram (EIC). Major ant or mite responses in the EIC were analyzed by molecular ion $(\mathrm{M}+\mathrm{H})^{+}$product scans of both the ant or mite samples and the 
corresponding frog skin sample to compare both retention times and mass spectra. To confirm putative shared compounds with similar mass-to-charge ratios $(\mathrm{m} / \mathrm{z}), 15 \mathrm{eV}$ collision energy product ion scan total ion chromatograms (TIC) were compared to confirm the presence of a coeluting compound in both the frog skin and the arthropod sample of interest (ant or mite). Finally, we compared of $15 \mathrm{eV}$ product ion mass spectra from each putative compound shared by the frog and corresponding arthropod sample to confirm the spectra closely match, suggesting the compound of interest is identical in both frogs and arthropods.

To compare stomach contents across 0 . sylvatica populations, we quantified the number and volume of ants, mites, beetles, and other arthropods. Each diet variable was normally distributed, an ANOVA was used to determine population differences in different diet categories. A Tukey's honest significance difference (HSD) test was used post-hoc to determine between population differences. A Benjimini Hochberg false discovery rate correction was applied to correct for multiple hypothesis testing.

\section{RESULTS}

\section{Little Devil Frog Populations Vary in Alkaloid Profiles}

We examined the alkaloid profiles from skin extracts of three Oophaga sylvatica populations background from fatty acids. Principal component analysis shows distinct clustering between

312 groups in principal component 1 , which accounts for $21 \%$ of the alkaloid variation. The Cristóbal

313 Colón population is centered between Felfa and Simón Bolívar (Figure 1c), which reflect their

314 geographic distribution. Overall populations show robust between-population differences and 315 little within-population variation (Online Resource Figures 1-3) with the exception of frogs 
collected from Cristóbal Colón. The most common compounds identified were 3,5-disubstituted indolizidines, 5,8-disubstituted indolizidines, decahydroquinolines, and lehmizidines (Table 1). Major alkaloids (the most abundant 5-6 alkaloids in each population) were mostly unique to a specific population, with overlap only between Cristóbal Colón and Simón Bolívar with the 5,8disubstituted indolizidine $231 \mathrm{C}$.

We examined in more detail the identity of alkaloids that differed in abundance between frog populations but were absent in control frogs fed crickets in captivity (Figure 2, Online Resource Figure 4). Two alkaloids were highly abundant in the Felfa population, and were shared with one of the other populations surveyed. Allopumiliotoxin 357A is present in both Felfa and Cristóbal Colón (ANOVA, $F_{3,20}=5.278, \mathrm{P}=0.046$ ) (Figure 2a) and izidine 211P is present in Felfa and Simón Bolívar populations (ANOVA, $F_{3,20}=11.439, \mathrm{P}=0.006$ ) (Figure $2 b$ ). Two unclassified alkaloids were more abundant in the Cristóbal Colón population. One unclassified alkaloid (Figure 2c) has a base peak of 202 (Online Resource Figure 4c), characteristic of some unclassified alkaloids (ANOVA, $F_{3,20}=8.192, \mathrm{P}=0.013$ ). The second unclassified alkaloid (Figure 2d) has a base peak of 204 (Online Resource Figure 4d), a characteristic of many unclassified alkaloids (ANOVA, $F_{3,20}=6.809, \mathrm{P}=0.021$ ). Two alkaloids were abundant in the Simón Bolívar population including izidine 239F (ANOVA, $F_{3,20}=5.798, \mathrm{P}=0.035$ ) and trans-2hexyl-5-heptyl-pyrrolidine (253I; ANOVA, $\left.F_{3,20}=6.615, \mathrm{P}=0.022\right)$ (Figure 2e-f; Online Resource

Fig 4e-f). Overall, our results show a unique profile of alkaloid toxins within each population, with little overlap between populations. This observation was replicated with LCMS data (Online Resource Figure 5).

\section{Dietary Differences Between Little Devil Frog Populations}

To gain a better understanding of how diet contributes to alkaloid profiles in these Little Devil 339 frog populations, we determined the quantity and identity of arthropods collected from the 340 stomach contents using both morphometric and molecular methods. We first grouped them into 341 broad categories of ants, mites, beetles, and "other" (Table 2) and calculated the number and 
342 volume of each arthropod type. With a subset of ants and mites from each population ( $N=5$

343 frogs per population), we used an untargeted metabolomics approach with LCMS to

344 characterize the chemical signature of consumed arthropods across frog populations. For the

345 remaining ants and mites, we sequenced the CO1 gene to characterize species diversity.

\section{Species and chemical diversity in consumed ants}

347 When characterizing broad patterns in ant consumption across frog populations (Table 2),

348 we found that the percentage of ants by volume varied between populations (ANOVA, $F_{2,32}=$ $3494.480, P=0.020)$, but the percentage of ants by number did not. Felfa had a higher percentage 350 of ants by volume compared to Simón Bolívar (Tukey's HSD, P $=0.015$ ) but not compared to 351 Cristóbal Colón (Tukey’s HSD, $\mathrm{P}=0.382$ ). Cristóbal Colón and Simón Bolívar did not differ in 352 the percentage of ants by volume.

To determine if consumed ants (pooled by individual frog) vary in their chemical profiles across Little Devil frog populations, we performed a principal component analysis of ant LCMS data (Figure 3a). We found that prey ant chemical profiles also cluster by the frog population from which they were isolated, suggesting the three 0 . sylvatica frog populations have access to different ant prey with distinct chemical profiles.

To better understand how ant prey may differ in these geographically distinct frog populations, we obtained CO1 sequence for 45 out of 137 ant specimens isolated from frog stomachs. Consumed ants belong to seven genera of the Myrmicinae sub-family (tribe Attini 361 [fungus-growing ants], genera: Cyphomyrmex, Octostruma, Pheidole, Sericomyrmex, Wasmannia; tribe Crematogastrini, genus: Crematogaster [acrobat ants]; tribe Solenopsidini, genus: Solenopsis [stinging ants]) and from one genus of the Formicidae Ectatomminae sub-

364 family (tribe Ectatommini, genus: Gnamptogenys [predatory ants]) (Figure 3b, Online Resource 365 Table 1). All the samples have more than $80 \%$ sequence similarity with their top BLASTn hit 366 matches and 22 have more than $96 \%$ similarity, sometimes allowing resolution at the species 
level. However, some specimens have close BLASTn matches (80-90\%) for different ant genera

368 (usually undescribed species), which do not allow confident assignment of some specimens.

Many specimens only had a match of up to $85 \%$ homology in $\mathrm{CO} 1$ sequence to records in the

GenBank database, suggesting these may be undescribed ant species.

Based on CO1 sequence similarity between ant specimens, we estimate 20 different

species of ants were recovered. Two genera of Myrmicinae Attini ants were recovered from frog

373 stomach contents across all three O. sylvatica populations, including Solenopsis and

374 Wasmannia. A unique species to the Felfa group is a Myrmicinae Crematogastrini

375 Crematogaster species, which was not observed in the two other frog populations. These

376 Crematogaster ants were found in the same Felfa frog (CJ 3132), and the closest match in the

377 GenBank database is only $86 \%$ similarity, suggesting these specimens represent an

378 undescribed ant species. A different Crematogaster species was isolated in a separate Felfa

379 frog (CJ 3138) and has 94\% similarity in CO1 sequence with Crematogaster nigropilosa. Four

380 ant specimens collected from both Felfa (CJ 3124) and Cristóbal Colón (CJ 3089) cluster with

381 Myrmicinae Attini Pheidole genera, although there is not an exact match with any described ant

382 CO1 sequences in the GenBank database. Finally, four specimens recovered from a Cristóbal

383 Colón (CJ 3089) are the only non-Myrmicinae ants we recovered. These specimens have 384 identical CO1 sequence with each other, and are $95 \%$ similar to the Ectatomminae 385 Gnamptogenys genera.

Species and chemical diversity in consumed mites

The amounts of mites consumed between populations varied (Table 2) The percentage of 388 mites in the stomach contents by number differed between populations (ANOVA, $F_{2,32}=4.232$, $389 P=0.024)$ where the Cristóbal Colón population had a higher percentage of mites by number 390 compared to both Felfa (Tukey's HSD, P = 0.042) and Simón Bolívar (Tukey's HSD P =0.044).

391 The percentage of mites by volume also varied between populations (ANOVA, $F_{2,25}=7.063, P=$ 
0.004), where Simón Bolívar frogs had a higher percentage of mites by volume in the stomach contents compared to Felfa (Tukey's HSD, $\mathrm{P}=0.003$ ).

To determine if the chemical profiles of consumed mites were distinct between frog populations, we performed a principal component analysis of the mite LCMS data (Figure 4a).

We found clustering of mite samples according to frog population in principal component 2 (12\% of variance) but not principal component 1 (13\% of variance).

We hypothesized that diversity in consumed mite species was responsible for the clustering of chemical profiles observed in the principal component analysis. To test this hypothesis, we obtained CO1 sequence for 9 out of 20 mites individually isolated from frog stomachs. Based on the top BLASTn hit for each mite, all specimens are likely Oribatid (Order Oribatida) mites (Figure 4b, Online Resource Table 2). However, due to the low percent similarity in CO1 sequence of most mites to the mites in the GenBank nr database (78-84\%), we were unable to assign mites to particular genera and many of these specimens likely represent undescribed species. An exception is one mite that has a $99 \%$ similarity to the mite Archegozetes longisetosus, and is likely the same species. Additionally three mites isolated from two Simón undescribed species. Thus, we have identified 5 undescribed and 1 described species of mites from the diet of three Oophaga sylvatica populations. Unfortunately, we did not obtain enough sequence information from separate mite specimens to conclusively determine how species

411 diversity drives chemical diversity observed in the mite LCMS data.

In addition to ants and mites, which together represent over $80 \%$ of the Oophaga sylvatica

414 diet, we also evaluated the number and volume of beetles and "other" arthropods isolated from

415 frog stomach contents (Table 2). However, the number of arthropods in these categories was so 416 low that we did not evaluate statistical differences between frog populations. Nearly all of the 
417 frogs from Cristóbal Colón had eaten at least one beetle (8 out of 10 frogs) whereas only 2

418 Simón Bolívar and 3 Felfa frogs had eaten a beetle. Very few arthropods were isolated that did

419 not group into the categories of ants, mites, or beetles (2 in Felfa, 5 in Simón Bolívar, and 4 in

420 Cristóbal Colón). These specimens were usually flies, wasps, or stinkbugs, although we did not

421 use molecular methods to identify these samples. We did not examine the chemical profiles of

422 non-mite or non-ant arthropods using LCMS.

\section{Poison Frog Alkaloids in Ants and Mites}

424 While the dietary specialization of poison frogs on ants and mites has been well 425 documented, less is known about which alkaloid compounds are derived from specific prey 426 categories. We compared three samples (frog skin, ants, and mites) for each of five individuals

427 from each population using LCMS, which gives increased sensitivity compared to GCMS. By

428 comparing all three samples within each individual, we were able to trace the dietary source of 429 four alkaloids.

$430 \quad$ Alkaloids Detected in Ants

431 We compared the LCMS responses in frog skin and their corresponding prey samples in 432 search of compounds that had similar mass to charge ratios in both the frog skin and the ants, 433 but not the mites. We then further examined these compounds with tandem mass spectrometry 434 to confirm the alkaloids found in frog skin and ants had similar fragmentation mass spectra 435 patterns, which suggests the compound of interest is identical in both samples.

$436 \quad$ Using this approach we identified ants as the dietary source of two frog alkaloids (Figure 5;

437 Online Resource Figure 6). In a Cristóbal Colón frog skin (CJ 3093) and the corresponding 438 sample of consumed ants (Figure 5a), we observed a compound with a mass to charge ratio of 439278 that also had identical fragmentation patterns in both samples, suggesting these 440 compounds are identical. Comparing the LCMS data to the GCMS data from the same frog skin 441 sample, we conclude that this ant-derived alkaloid is lehmizidine 277A. Similarly, we identified a 
response in a Felfa frog (CJ 3129) and consumed ants from that same frog (Figure 5b). This compound has a mass to charge ratio of 204 , and the fragmentation patterns show the mass

444 spectra closely match, suggesting identical compounds in both frog and ant samples. From

445 comparison of GCMS responses with $\mathrm{m} / \mathrm{z} 204$ in this same frog skin sample, this alkaloid is

446 likely 5,8-disubstituted indolizidine 203A.

\section{$447 \quad$ Alkaloids Detected in Mites}

448 We took a similar approach to detect common LCMS responses in frog skin and their 449 corresponding mite samples, where compounds should have similar mass to charge ratios in 450 both the frog skin and the mites, but not the ants. Further examination of these compounds with 451 tandem mass spectrometry confirmed the alkaloids found in frog skin and mites are identical.

452 Using this comparative LCMS approach, we identified mites as the dietary source of two 453 poison frogs alkaloids (Figure 6, Online Resource Figure 6). In a Cristóbal Colón frog (CJ 454 3091), a similar LCMS response with a mass to charge ratio of 224 was observed in both the 455 frog skin and the pooled mite sample (Figure 6a). Comparison of the tandem mass spectrometry fragmentation pattern shows the spectra closely match, suggesting the 457 compounds detected in these samples are identical. From comparison of the GCMS responses 458 with a mass to charge ratio of 224 in this same frog skin sample, this compound is likely $3,5-$ 459 disubstituted indolizidine 223AB. In a separate frog-mite comparison, a similar LCMS response 460 with a mass to charge ratio of 292 was observed in a Simón Bolívar frog (CJ 3112) and the 461 pooled mites from the frog's stomach (Figure 6b). Fragmentation mass spectra of the 462 compounds suggest this compound is identical. From the GCMS analysis of the frog skin 463 sample, no corresponding alkaloid with a similar mass to charge ratio was detected, likely from 464 the lack of sensitivity of this method compared to LCMS. 
We have shown that Oophaga sylvatica populations vary in defensive chemical profiles in a manner that reflects prey arthropod chemical diversity. We used mass spectrometry to identify

469 the arthropod source of four alkaloid toxins by comparing frog skin chemistry to arthropods 470 isolated from the stomach contents of the same frogs. Overall our results highlight the diversity

471 of chemical defenses found in O. sylvatica and Ecuadorean ants and mites, adding to the

472 growing literature of the trophic relationships of poison frog toxins and their arthropod sources.

\section{Little Devil frog defensive chemicals}

We used GCMS to determine the repertoire of defensive chemicals across three Oophaga sylvatica populations. We observed in a principal component analysis of frog alkaloid data that 476 populations clustered along their latitudinal gradient. Research on poison frog population 477 differences in alkaloid toxins have recently focused on the Strawberry poison frog (Oophaga 478 pumilio) in Costa Rica and Panama (Saporito et al. 2006; Saporito et al. 2007a; Saporito et al. 479 2010; Saporito et al. 2012), and to a lesser extent the Imitator frog (Ranitomeya imitator) in Peru 480 (Stuckert et al. 2014). These studies have also shown greater similarity in alkaloid profiles with geographic proximity (Saporito et al. 2007a). Variation in alkaloid profiles among populations has been described for some $O$. sylvatica populations (under the name Dendrobates histrionicus), as well as a number of other Oophaga species, including O. histrionica and $O$. lehmanni (Myers and Daly 1976). Dietary environment seems to be a significant component of toxin profiles within Oophaga. For example, sympatric populations of O. granulifera and $O$. pumilio have more similar alkaloid profiles than the geographically distant populations of $O$. 487 granulifera (Myers et al. 1995). However, this is not always the case as co-mimetic (sympatric) 488 species of Ranitomeya differ in their alkaloid profiles (Stuckert et al. 2014), which may suggest 489 variation in micro-habitats, contrasting prey preferences, or genetic differences that impact the 490 efficiency and specificity of alkaloid sequestration. Clearly more comparative work across 
broader range of species and habitats are required to fully understand how these ecological and genetics factors impact frog chemical defenses.

The most abundant classes of alkaloids in Oophaga sylvatica were 3,5- or 5,8-disubstituted

494 indolizidines, although the precise alkaloid in these classes differed between the three

495 populations (Table 1). This is in contrast to toxin profiles for this species collected from Ecuador

496 by Myers and Daly (Daly et al. 1978) who reported only histrionicotoxins as the major alkaloids

497 in several populations, which we only detected in Cristóbal Colón frogs. This discrepancy could

498 be due to sampling location as O. sylvatica in the (Myers and Daly 1976) study were collected in

499 southernmost part of their range. Other possibility is could be changes in dietary arthropod

500 composition over the past 40 years, which may have shifted the most abundant alkaloids in this

501 species from histrionicotoxins to disubstituted indolizidines. The unique major alkaloids in

502 Cristóbal Colón compared to Felfa and Simón Bolívar include histrionicotoxin 285A and

503 lehmizidines $277 \mathrm{~A}$ and 275A. Only Felfa frogs had decahydroquinolines (DHQ 195A and 223F)

504 as a major alkaloid group. Many of the alkaloids we have identified in 0 . sylvatica have also

505 been detected in O. pumilio (Saporito et al. 2007a), with the exception of 5,8-I 245C and Izidine

506 239F, and some Mantellas (Garraffo et al. 1993).

507 Individual variation in alkaloid profiles was limited in the Simón Bolívar and Felfa

508 populations, but was much greater in the Cristóbal Colón population where almost all frogs had

509 strikingly different alkaloid profiles. The general diet of Cristóbal Colón frogs did not drastically

510 differ and without genetically profiling their stomach contents (which were instead used for

511 LCMS quantification of alkaloids), we are unable to determine the species diversity of their diets,

512 which we predict from the alkaloids profiles to be very different. However, it should be noted that

513 quantification of stomach contents represents a snapshot in time and may not be representative

514 of the full dietary repertoire that contributed to skin alkaloid profiles accumulated over weeks or

515 months. Additionally, frogs that had high alkaloid peaks around 16-19 minutes by GCMS were 
516 all male, whereas the other two frogs with low alkaloid levels around this time point were female.

517 It could be that there are sex differences in toxin sequestration within the population, as has

518 been documented in some O. pumilio populations (Saporito et al. 2010). However, this is

519 unlikely as both males and females were included in the Simón Bolívar and Felfa populations,

520 which did not show a high degree of individual variation within the population. There are two

521 more plausible explanations for this individual variation. First, frog age may be a contributing

522 factor to alkaloid diversity as was recently documented in the Brazilian red-belly toad

523 (Melanophryniscus moreirae) (Jeckel et al. 2015). Unfortunately, we were unable to determine

524 the age of the O. sylvatica frogs, although this is likely an important variable to consider in future

525 studies. Secondly, frogs may have been collected in different microhabitats and this difference

526 in diet availability may influence alkaloid profiles. This has been recently observed in Mantellas

527 where frogs from disturbed habitats have a higher diversity in alkaloids than frogs from

528 undisturbed habitats (Andriamaharavo et al. 2010). Further sampling and broader analyses of

529 potential contributing factors within the Cristóbal Colón population would be required to fully

530 understand these individual differences in alkaloid profiles.

\section{Arthropod diversity in the diet of poison frogs}

The poison frog dietary specialization on ants and mites is well established (Caldwell 1996; et al. 2009). We found that the stomach contents of the three Oophaga sylvatica populations contained over $80 \%$ ants and mites by number. Ants in particular composed at least $50 \%$ of the diet in these populations. Our results are similar to those of O. histrionica (Osorio et al. 2015), a

538 closely related species in Colombia, whose diet is mainly composed of Formicidae (ants), Acari 539 (mites), and Coleoptera (beetles). These three arthropod families account for over $97 \%$ of the 540 diet (by number) of the three O. sylvatica populations we investigated. We found that Felfa frogs 
541 tended to have more ants in the stomach contents, and ants have been proposed to contain

542 mostly unbranched alkaloids (Saporito et al. 2012). We also identified DHQs 195A and 223F as

543 major alkaloids in Felfa, which have an ant origin (Jones et al. 1999). On the other hand, both

544 Cristóbal Colón and Simón Bolívar populations had higher proportion of mites in their stomach

545 contents (either by number or volume, respectively), which have been proposed as the main

546 source of branched-chain alkaloids (Saporito et al. 2007b; Saporito et al. 2011).

Ants. Ant genera diversity and chemical variation reflects the heterogeneity of Oophaga

549 frog population in a principal component analysis, suggesting geographic differences in toxin

550 availability within frog prey items. We identified ant genera in 0 . sylvatica stomachs that are

551 often consumed by other poison frogs such as Pheidole, Crematogaster, Cyphomyrmex,

552 Octostruma, Gnamptogenys, Solenopsis and Wasmannia (Gómez-Hoyos et al. 2014; Mebs et

553 al. 2014; Osorio et al. 2015). Most of the consumed ants were in the Subfamily Myrmicinae

554 Tribe Attini, the fungus-cultivating ants. Specimens in the genus Solenopsis were present in all

555 frog populations, but likely represent different species or subspecies given their diversity in CO1

556 sequence and morphology. Recently the genus Solenopsis was identified as a source for

557 histrionicotoxin (Jones et al. 2012), and we detected the presence histrionicotoxin in Cristóbal

558 Colón frogs that also ate Solenopsis ants. However it should be noted that although Solenopsis

559 species and histrionicotoxins were observed in Cristóbal Colón, we did not detect

560 histrionicotoxins in Felfa or Simón Bolívar frogs, which also ate Solenopsis ants. This

561 discrepancy is a caution against assuming every Solenopsis ant species is chemically similar or

562 that every ingested arthropod found in a poison frog stomach contributes to the alkaloid

563 repertoire of the frog. Finally, Pheidole ants are also known to be predators of Oribatid mites

564 (Wilson 2005), which can carry alkaloid toxins also identified in frogs. This raises the possibility 
of toxin transfer from mites through ants to frogs, as well as from mites to frogs directly

566 (Saporito et al. 2011).

Mites. We found the genera and chemical diversity of mites partially reflects the variation in toxin profiles across Oophaga sylvatica populations. We sequenced the CO1 region from 9 mite specimens representing 6 undescribed species. We initially isolated 20 mites from frog stomachs, but the low success rate of $\mathrm{CO} 1$ amplification is likely due the small amount of genomic DNA we were able to extract from these tiny arthropods. The closest match in the

572 GenBank nr database for all samples are Oribatid mites, which are a source of many poison

573 frog alkaloids (Saporito et al. 2007b). Interestingly, Saporito et al. (Saporito et al. 2011; Saporito

574 et al. 2015) has shown Oribatid mites carry many alkaloids found on poison frogs as well as

575 many other non-frog alkaloids. A recent study has shown tropical mites carry more alkaloids

576 than temperate mites (Saporito et al. 2015), although it is not clear if poison frog alkaloid

577 variation reflects diversity in Oribatid mite species across a smaller longitudinal gradient. Our principal component analysis of mite metabolomics data shows only partial clustering by frog populations, but more chemical profiling of mites is needed to determine how they contribute to geographic variation in poison frog toxin profiles. Interestingly, Oribatid mites seem to vary in alkaloid profiles based on developmental stage, and (Saporito et al. 2011) suggest this may 582 indicate mites synthesize these alkaloids themselves. However, only plants, bacteria, and fungi 583 have been demonstrated to have the enzymatic pathways necessary to synthesize alkaloid 584 neurotoxins (Ashihara et al. 2008; Osswald et al. 2007; Waller 2012; Wiese et al. 2010), and so 585 it remains to be determined if mites themselves synthesize alkaloids or if they obtain these small 586 molecules from plants or microbes. Regardless of the alkaloid origin in mites, they are clearly a 587 rich biochemical resource for poison frog chemical defense and should be studied in this context 588 more systematically.

\section{Tracing the source of poison frog toxins}


Since the dietary hypothesis of poison frog toxicity was proposed in the 1990s (Daly et al. 1994a; Daly et al. 1994b), there has been a strong focus on identifying the arthropods harboring

592 these alkaloid chemicals. Many of the alkaloid classes have been identified in either ants or 593 mites (or both) (Santos et al. 2015; Saporito et al. 2012; Saporito et al. 2009) found sympatry 594 with poison frogs. For example, histrionicotoxins and pumiliotoxins have been identified in ants 595 (Jones et al. 2012; Saporito et al. 2004). However, it has been historically difficult to identify 596 poison frog alkaloids in arthropods given their small size and low alkaloid content per specimen 597 as well as difficulty in obtaining species that poison frogs have been known to ingest from the 598 leaf litter, especially extremely small mites.

599 To identify the arthropod source of Oophaga sylvatica toxins, we took a simple approach of 600 pooling separately the ants and mites found in the frogs' stomachs. This allowed us to examine 601 the chemistry of arthropods the frogs ingested rather than surveying the general surrounding leaf litter that may contain many arthropods the frogs do not eat. Moreover, the high sensitivity of LCMS allowed us to detect small quantities of alkaloids that may be undetectable by GCMS. However, because the alkaloid data library by Daly and colleagues is based on GCMS results (Daly et al. 2005), examining frog skin alkaloids must be done with both GCMS (for alkaloid identification) and LCMS (for comparison with arthropod data). This dual approach allowed us to 607 identify the arthropod source of three alkaloids (277A, 203A, and 223AB), but for one alkaloid we were not able to tentatively assign an identity given it was not at detectable levels using GCMS. It is important to note that our experimental design for LCMS limits our ability to identify the exact species of ant or mite from which alkaloid is found. Although we photographed the 611 arthropods prior to alkaloid extraction, we cannot reliably identify the species within the pooled 612 sample without genetic testing. New methods involving DNA barcoding of fecal samples to 613 characterize diet (Kartzinel and Pringle 2015) may be a useful tool in the future to genetically 614 identify small arthropod prey without sacrificing frogs for stomach content analysis. Finally, it is 
615 important to note that the LCMS profiling of stomach contents represents a snapshot in time.

616 Many frog alkaloids were not detected in the arthropod samples given they do not represent the

617 full repertoire of dietary diversity in these frogs. The pharmacokinetics of toxin sequestration in

618 poison frogs is unknown, and some frog toxins could have been acquired weeks to months prior

619 to our sampling. A combination of non-invasive and repeated sampling of prey arthropods and

620 frog skin toxins would be a good step forward to resolving some of the pitfalls of standard

621 methods in this field.

622 To our knowledge, we have provided the first evidence of the dietary source of three alkaloid

623 toxins. We found lehmizidine $277 \mathrm{~A}$ in frogs of the Cristóbal Colón population and traced the

624 dietary source of this toxin to ants. Ants have been the proposed source of lehmizidines for

625 poison frogs since monosubstituted lehmizidines occur in a myrmicine ant (Jones et al. 2007),

626 but we provide here the first evidence for this trophic relationship. We were also able to identify

627 ants as the source of 5,8-disubstituted indolizidine 203A in frogs from Felfa. Other alkaloids in

628 this class have been identified in both ants and mites (Daly et al. 2002; Saporito et al. 2007b).

629 Finally, we were able to trace the source of 3,5-disubstituted indolizidine 223AB in Cristóbal

630 Colón frogs to mites. Other alkaloids in this class have also been attributed to both ants and

631 mites (Jones et al. 1999; Saporito et al. 2007b). Finally, although we were able to identify an

632 alkaloid (m/z 292) in both frog skin from Simón Bolívar and mites found in that same frogs'

633 stomach, we were unable to tentatively identify the alkaloid given the lack of LCMS library data

634 for these chemicals. It is the partnership between biologists and chemists (largely John Daly,

635 (Savitzky and Saporito 2012)) that has driven the field of chemical ecology in poison frogs

636 forward. With emerging new technologies, such interdisciplinary partnerships are still necessary

637 for progress.

638 Summary 
We have described here the alkaloid profiles of three populations of Oophaga sylvatica, the

640 arthropods that compose their distinctly different diets, and have identified the dietary source of

641 four poison frog alkaloids. Moreover, our results highlight how arthropod species and chemical

642 diversity drives variation in poison frog chemical defenses. Future work will focus on identifying

643 the arthropod species that harbor these alkaloids, tracing the source of these toxins to the

644 plants or microbes that synthesize them and profiling additional O. sylvatica populations.

\section{Acknowledgements}

647 We are grateful to Jon Clardy, Andrew Murray, and Adam Stuckert for comments on early 648 versions of the manuscript. This work was funded by the Explorers' Club 2014 Youth Activity 649 Grant, the Harvard Museum of Comparative Zoology's Myvanwy M. and George M. Dick 650 Scholarship Fund for Science Students, and a grant from the Harvard College Research 651 Program to JRM, the Myvanwy M. and George M. Dick Scholarship Fund for Science Students 652 and the Harvard College Research Program to SNC, and a Bauer Fellowship from Harvard 653 University, the L'Oreal For Women in Science Fellowship, and the William F. Milton Fund from 654 Harvard Medical School to LAO. EET and LAC acknowledges the support of Wikiri and the 655 Saint Louis Zoo. 


\section{REFERENCES}

Andriamaharavo NR, Garraffo HM, Saporito RA, Daly JW, Razafindrabe CR, Andriantsiferana M, Spande TF (2010) Roughing It: A Mantellid Poison Frog Shows Greater Alkaloid Diversity in Some Disturbed Habitats\# J Nat Prod 73:322-330

Ashihara H, Sano H, Crozier A (2008) Caffeine and related purine alkaloids: biosynthesis, catabolism, function and genetic engineering Phytochemistry 69:841-856

Caldwell JP (1996) The evolution of myrmecophagy and its correlates in poison frogs (Family Dendrobatidae) Journal of Zoology 240:75-101

Casewell NR, Wüster W, Vonk FJ, Harrison RA, Fry BG (2013) Complex cocktails: the evolutionary novelty of venoms Trends in ecology \& evolution 28:219-229

Daly JW (1995) The chemistry of poisons in amphibian skin Proceedings of the National Academy of Sciences 92:9-13

Daly JW, Brown GB, Mensah-Dwumah M, Myers CW (1978) Classification of skin alkaloids from neotropical poison-dart frogs (Dendrobatidae) Toxicon 16:163-188

Daly JW, Garraffo HM, Spande TF, Jaramillo C, Rand AS (1994a) Dietary source for skin alkaloids of poison frogs (Dendrobatidae)? Journal of Chemical Ecology 20:943-955

Daly JW, Kaneko T, Wilham J, Garraffo HM, Spande TF, Espinosa A, Donnelly MA (2002) Bioactive alkaloids of frog skin: combinatorial bioprospecting reveals that pumiliotoxins have an arthropod source Proceedings of the National Academy of Sciences 99:1399614001

Daly JW, Secunda SI, Garraffo HM, Spande TF, Wisnieski A, Cover Jr JF (1994b) An uptake system for dietary alkaloids in poison frogs (Dendrobatidae) Toxicon 32:657-663

Daly JW, Spande TF (1986) Amphibian alkaloids: chemistry, pharmacology and biology Alkaloids: chemical and biological perspectives 4:1-274

Daly JW, Spande TF, Garraffo HM (2005) Alkaloids from amphibian skin: a tabulation of over eight-hundred compounds J Nat Prod 68:1556-1575

Darst CR, Cummings ME (2006) Predator learning favours mimicry of a less-toxic model in poison frogs Nature 440:208-211

Darst CR, Menéndez - Guerrero PA, Coloma LA, Cannatella DC (2005) Evolution of dietary specialization and chemical defense in poison frogs (Dendrobatidae): A comparative analysis The American Naturalist 165:56-69

Donnelly MA (1991) Feeding patterns of the strawberry poison frog, Dendrobates pumilio (Anura: Dendrobatidae) Copeia:723-730

Doyle JJ (1987) A rapid DNA isolation procedure for small quantities of fresh leaf tissue Phytochem bull 19:11-15

Folmer O, Black M, Hoeh W, Lutz R, Vrijenhoek R (1994) DNA primers for amplification of mitochondrial cytochrome c oxidase subunit I from diverse metazoan invertebrates Molecular marine biology and biotechnology 3:294-299

Garraffo H, Caceres J, Daly J, Spande T, Andriamaharavo N, Andriantsiferana M (1993) Alkaloids in Madagascan frogs (Mantella): pumiliotoxins, indolizidines, quinolizidines, and pyrrolizidines J Nat Prod 56:1016-1038

Gómez-Hoyos DA, López-García MM, Soto-Garzón CA, Méndez-Rojas DM, Kahn TR, Velasco JA (2014) Geographic variation in the diet of the Cauca Poison Frog Andinobates bombetes (Anura: Dendrobatidae) in the Andes of Colombia Herpetology Notes 7:559564

Hantak MM, Grant T, Reinsch S, Mcginnity D, Loring M, Toyooka N, Saporito RA (2013) Dietary alkaloid sequestration in a poison frog: an experimental test of alkaloid uptake in Melanophryniscus stelzneri (Bufonidae) Journal of chemical ecology 39:1400-1406

Heckel DG (2014) Insect detoxification and sequestration strategies Annual Plant Reviews volume 47: Insect-Plant Interactions:77-114 
707

708

709

710

711

712

713

714

715

716

717

718

719

720

721

722

723

724

725

726

727

728

729

730

731

732

733

734

735

736

737

738

739

740

741

742

743

744

745

746

747

748

749

750

751

752

753

754

755

756

757
Jeckel AM, Saporito RA, Grant T (2015) The relationship between poison frog chemical defenses and age, body size, and sex Frontiers in zoology 12:27

Jones TH, Adams RM, Spande TF, Garraffo HM, Kaneko T, Schultz TR (2012) Histrionicotoxin alkaloids finally detected in an ant J Nat Prod 75:1930-1936

Jones TH et al. (1999) Further alkaloids common to ants and frogs: decahydroquinolines and a quinolizidine Journal of Chemical Ecology 25:1179-1193

Jones TH et al. (2007) Venom chemistry of the ant Myrmicaria melanogaster from Brunei J Nat Prod 70:160-168

Kambhampati S, Smith P (1995) PCR primers for the amplification of four insect mitochondrial gene fragments Insect molecular biology 4:233-236

Kartzinel TR, Pringle RM (2015) Molecular detection of invertebrate prey in vertebrate diets: trophic ecology of Caribbean island lizards Molecular ecology resources

Mebs D, Alvarez JV, Pogoda W, Toennes SW, Köhler G (2014) Poor alkaloid sequestration by arrow poison frogs of the genus Phyllobates from Costa Rica Toxicon 80:73-77

Meusnier I, Singer GA, Landry J-F, Hickey DA, Hebert PD, Hajibabaei M (2008) A universal DNA mini-barcode for biodiversity analysis BMC genomics 9:214

Myers CW, Daly JW (1976) Preliminary evaluation of skin toxins and vocalizations in taxonomic and evolutionary studies of poison-dart frogs (Dendrobatidae) Bulletin of the American Museum of Natural History 157:173-262

Myers CW, Daly JW, Garraffo HM, Wisnieski A, Cover JF (1995) Discovery of the Costa Rican poison frog Dendrobates granuliferus in sympatry with Dendrobates pumilio, and comments on taxonomic use of skin alkaloids. American Museum novitates; no. 3144

Navajas M, Lagnel J, Gutierrez J, Boursot P (1998) Species-wide homogeneity of nuclear ribosomal ITS2 sequences in the spider mite Tetranychus urticae contrasts with extensive mitochondrial COI polymorphism Heredity 80:742-752

Neuwirth M, Daly JW, Myers CW, Tice LW (1979) Morphology of the Granular Secretory Glands in Skin of Poison-Dart Frogs (Dendrobatidae) Tissue Cell 11:755-771 doi:Doi 10.1016/0040-8166(79)90029-6

Olivera BM et al. (1985) Peptide neurotoxins from fish-hunting cone snails Science 230:13381343

Opitz SE, Müller C (2009) Plant chemistry and insect sequestration Chemoecology 19:117-154

Osorio D, Valenzuel L, Bermudez-Rivas C, Castaño S (2015) Descripción de la dieta de una población de Oophaga histrionica (Athesphatanura: Dendrobatidae) en un enclave seco del Valle del Cauca, Colombia Revista Biodiversidad Neotropical 5:29-35

Osswald J, Rellán S, Gago A, Vasconcelos V (2007) Toxicology and detection methods of the alkaloid neurotoxin produced by cyanobacteria, anatoxin-a Environment international 33:1070-1089

Rodríguez A, Poth D, Schulz S, Vences M (2011) Discovery of skin alkaloids in a miniaturized eleutherodactylid frog from Cuba Biology letters 7:414-418

Santos JC, Coloma LA, Cannatella DC (2003) Multiple, recurring origins of aposematism and diet specialization in poison frogs $P$ Natl Acad Sci USA 100:12792-12797 doi:Doi 10.1073/Pnas.2133521100

Santos JC, Tarvin RD, O'Connell LA (2015) A review of chemical defense in poison frogs (Dendrobatidae): Ecology, pharmacokinetics and autoresistance. In: Chemical Signals in Vertebrates. Springer Science \& Business Media, $p$ in press

Saporito RA, Donnelly MA, Garraffo HM, Spande TF, Daly JW (2006) Geographic and seasonal variation in alkaloid-based chemical defenses of Dendrobates pumilio from Bocas del Toro, Panama Journal of chemical ecology 32:795-814

Saporito RA, Donnelly MA, Jain P, Garraffo HM, Spande TF, Daly JW (2007a) Spatial and temporal patterns of alkaloid variation in the poison frog Oophaga pumilio in Costa Rica and Panama over 30 years Toxicon 50:757-778 
758

759

760

761

762

763

764

765

766

767

768

769

770

771

772

773

774

775

776

777

778

779

780

781

782

783

784

785

786

787

788

789

790

791

792

793

794

795

796

797

798

799

800

801

802

803

804

805

Saporito RA, Donnelly MA, Madden AA, Garraffo HM, Spande TF (2010) Sex-Related Differences in Alkaloid Chemical Defenses of the Dendrobatid Frog Oophaga pumilio from Cayo Nancy, Bocas del Toro, Panama J Nat Prod 73:317-321 doi:Doi 10.1021/Np900702d

Saporito RA, Donnelly MA, Norton RA, Garraffo HM, Spande TF, Daly JW (2007b) Oribatid mites as a major dietary source for alkaloids in poison frogs Proceedings of the National Academy of Sciences 104:8885-8890

Saporito RA, Donnelly MA, Spande TF, Garraffo HM (2012) A review of chemical ecology in poison frogs Chemoecology 22:159-168 doi:Doi 10.1007/S00049-011-0088-0

Saporito RA, Garraffo HM, Donnelly MA, Edwards AL, Longino JT, Daly JW (2004) Formicine ants: an arthropod source for the pumiliotoxin alkaloids of dendrobatid poison frogs Proceedings of the National Academy of Sciences of the United States of America 101:8045-8050

Saporito RA, Norton RA, Andriamaharavo NR, Garraffo HM, Spande TF (2011) Alkaloids in the mite Scheloribates laevigatus: further alkaloids common to oribatid mites and poison frogs Journal of chemical ecology 37:213-218

Saporito RA, Norton RA, Garraffo MH, Spande TF (2015) Taxonomic distribution of defensive alkaloids in Nearctic oribatid mites (Acari, Oribatida) Experimental and Applied Acarology 67:317-333

Saporito RA, Spande TF, Garraffo HM, Donnelly MA (2009) Arthropod alkaloids in poison frogs: a review of the dietary hypothesis Heterocycles 79:277-297

Savitzky AH, Saporito RA (2012) Sequestration of defensive toxins by tetrapod vertebrates: contributions in memory of John W. Daly Chemoecology 22:139-140

Smith MA, Fisher BL, Hebert PD (2005) DNA barcoding for effective biodiversity assessment of a hyperdiverse arthropod group: the ants of Madagascar Philosophical Transactions of the Royal Society B: Biological Sciences 360:1825-1834

Storey JD (2003) The positive false discovery rate: a Bayesian interpretation and the q-value Annals of statistics:2013-2035

Stuckert AM, Saporito RA, Venegas PJ, Summers K (2014) Alkaloid defenses of co-mimics in a putative Müllerian mimetic radiation BMC evolutionary biology 14:76

Takada W, Sakata T, Shimano S, Enami Y, Mori N, Nishida R, Kuwahara Y (2005) Scheloribatid Mites as the Source of Pumiliotoxins in Dendrobatid Frogs $†$ Journal of chemical ecology 31:2403-2415

Tamura K, Stecher G, Peterson D, Filipski A, Kumar S (2013) MEGA6: molecular evolutionary genetics analysis version 6.0 Molecular biology and evolution 30:2725-2729

Tautenhahn R, Patti GJ, Rinehart D, Siuzdak G (2012) XCMS Online: a web-based platform to process untargeted metabolomic data Analytical chemistry 84:5035-5039

Toft CA (1980) Feeding ecology of thirteen syntopic species of anurans in a seasonal tropical environment Oecologia 45:131-141

Waller G (2012) Alkaloid biology and metabolism in plants. Springer Science \& Business Media,

Wiese M, D'agostino PM, Mihali TK, Moffitt MC, Neilan BA (2010) Neurotoxic alkaloids: saxitoxin and its analogs Marine drugs 8:2185-2211

Wilson E (2005) Oribatid mite predation by small ants of the genus Pheidole Insectes Sociaux 52:263-265

Young MR, Behan-Pelletier VM, Hebert PD (2012) Revealing the hyperdiverse mite fauna of subarctic Canada through DNA barcoding 
bioRxiv preprint doi: https://doi.org/10.1101/031849; this version posted November 15,2015 . The copyright holder for this preprint (which was not certified by peer review) is the author/funder, who has granted bioRxiv a license to display the preprint in perpetuity. It is made available under aCC-BY-ND 4.0 International license.

807 TABLE 1. MAJOR ALKALOIDS IDENTIFIED IN Oophaga sylvatica

\begin{tabular}{|c|c|c|c|c|}
\hline Alkaloid & & Felfa & Cristóbal Colón & Simón Bolívar \\
\hline Histrionicotoxin 285A & & & + & \\
\hline 3,5-Disubstituted indolizidine 275C & & & & + \\
\hline \multicolumn{5}{|l|}{ 5,8-Disubstituted indolizidines } \\
\hline & 203A & + & & \\
\hline & 207A & & & + \\
\hline & 231C & & + & + \\
\hline & 247E & + & & \\
\hline & 245C & & + & \\
\hline \multicolumn{5}{|l|}{ Decahydroquinolines } \\
\hline & 195A & + & & \\
\hline & 223F & + & & \\
\hline $5,6,8-T r i s u b s t i t u t e d$ indolizidine 209 & & & & + \\
\hline \multicolumn{5}{|l|}{ Lehmizidines } \\
\hline & 277A & & + & \\
\hline & 275A & & + & \\
\hline Izidine 239F & & & & + \\
\hline Unknown Structures 223C & & & + & \\
\hline
\end{tabular}

TABLE 2. BROAD DIET CHARACTERIZATION OF FELFA, CRISTÓBAL COLÓN, AND SIMÓN BOLIVAR POPULATIONS

\begin{tabular}{llllllllll}
\hline Population & $\mathbf{N}$ & $\begin{array}{l}\text { No. prey per frog } \\
\text { (mean (min \& max)) }\end{array}$ & $\begin{array}{l}\text { \% ants } \\
\text { (num) }\end{array}$ & $\begin{array}{l}\text { \% ants } \\
\text { (vol) }\end{array}$ & $\begin{array}{l}\text { \% mites } \\
\text { (num) }\end{array}$ & $\begin{array}{l}\text { \% mites } \\
\text { (vol) }\end{array}$ & $\begin{array}{l}\text { \% beetles } \\
\text { (num) }\end{array}$ & $\begin{array}{l}\text { \% beetles } \\
\text { (vol) }\end{array}$ \\
\hline Felfa & 10 & $12.6(6-33)$ & 78.72 & 85.81 & 15.86 & 6.825 & 3.693 & 7.317 \\
Cristóbal Colón & 10 & $9.6(4-31)$ & 54.37 & 70.15 & 35.10 & 19.69 & 8.545 & 6.392 \\
Simón Bolívar & 12 & $12.5(1-40)$ & 66.45 & 52.55 & 16.81 & 22.96 & 14.26 & 18.08 \\
\hline
\end{tabular}


Figure 1
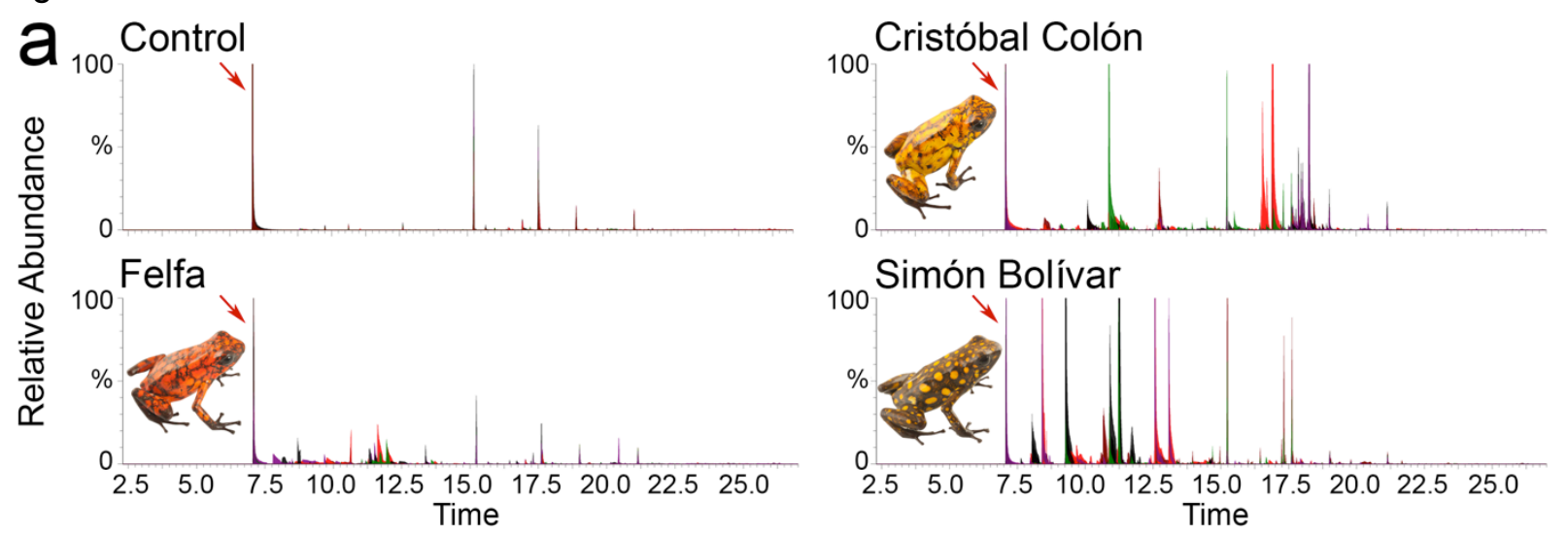

b

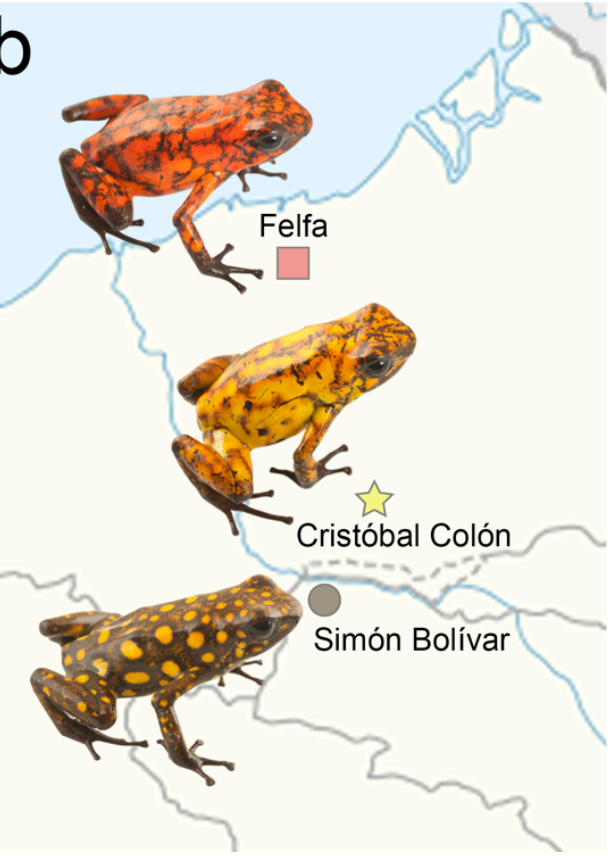

$C^{3}$
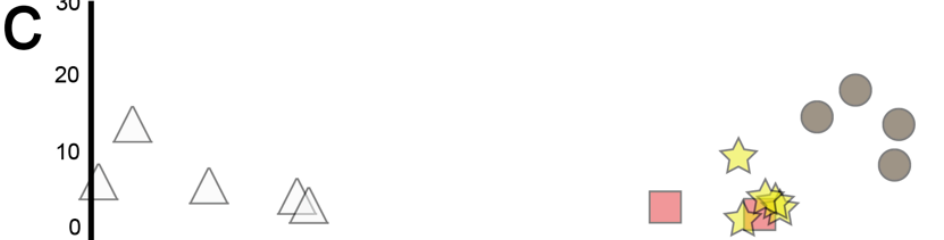

Figure 1. Little Devil frog (Oophaga sylvatica) population variation in chemical defenses. (a) Alkaloid toxin profiles assayed by gas chromatography mass spectrometry (GCMS) show population variation in chemical defenses where each peak is a chemical and peak amplitude represents abundance ( $\mathrm{N}=5$ per group). Overlaid colors represent different individuals (individual plots can be seen in supplementary materials). Note control (captive) frogs are rendered non-toxic with a diet of crickets and fruit flies; major peaks are skin fatty acids (not alkaloids) and benzocaine (used for euthanasia). Red sylvatica frog populations in northwestern Ecuador. (c) Principal component analysis of GCMS profiles reveals clustering of populations along a latitudinal gradient. 
Figure 2

b
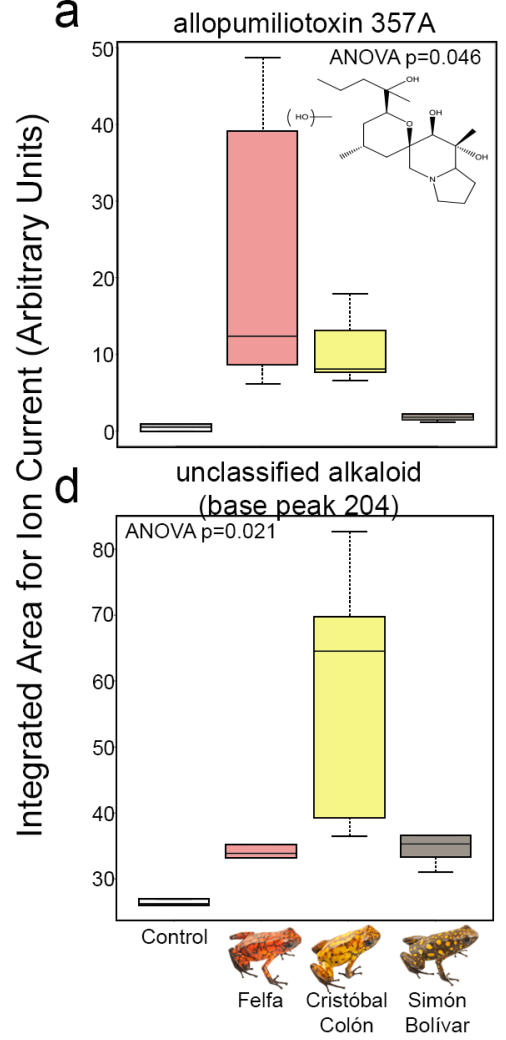

izidine 211P

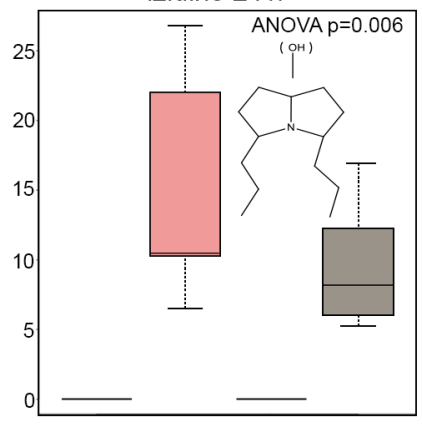

e izidine 239F

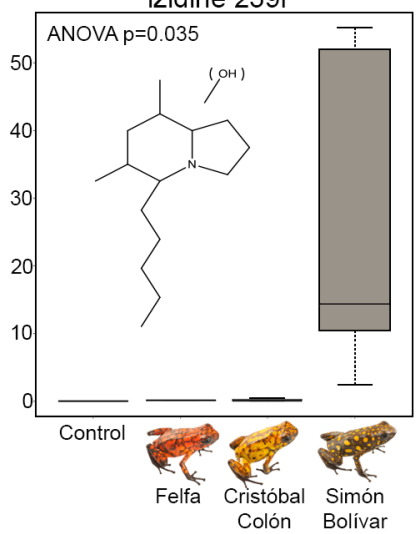

C unclassified alkaloid

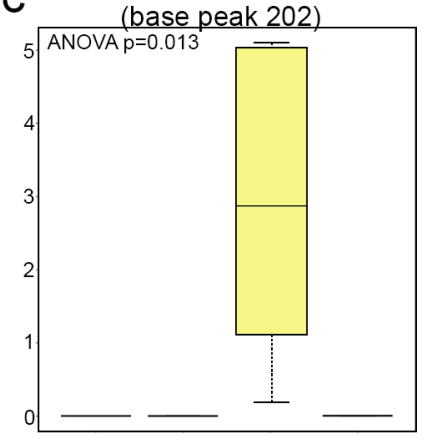

$f_{2,5 \text {-disubstituted pyrrolidine } 2531}$

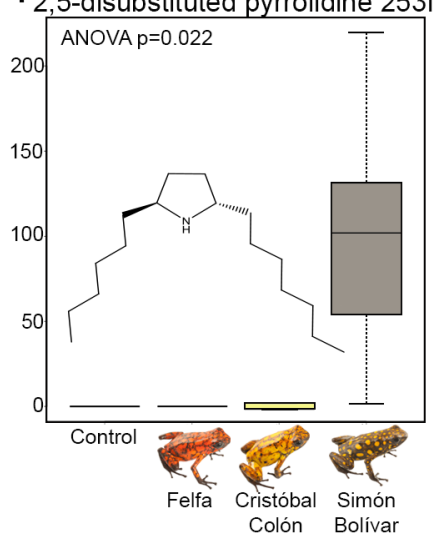

Figure 2. Each Little Devil frog (Oophaga sylvatica) population has a unique profile of defensive chemicals. Boxplots show relative abundance of various alkaloids between control (captive frogs; white) and wild populations of $O$. sylvatica, including Felfa (red), Cristóbal Colón (yellow), and Simón Bolívar (brown). GCMS extracted ion mass spectrum used for identification is shown in Supplementary Figure 4. Alkaloid structures are shown in each figure where known. 
Figure 3
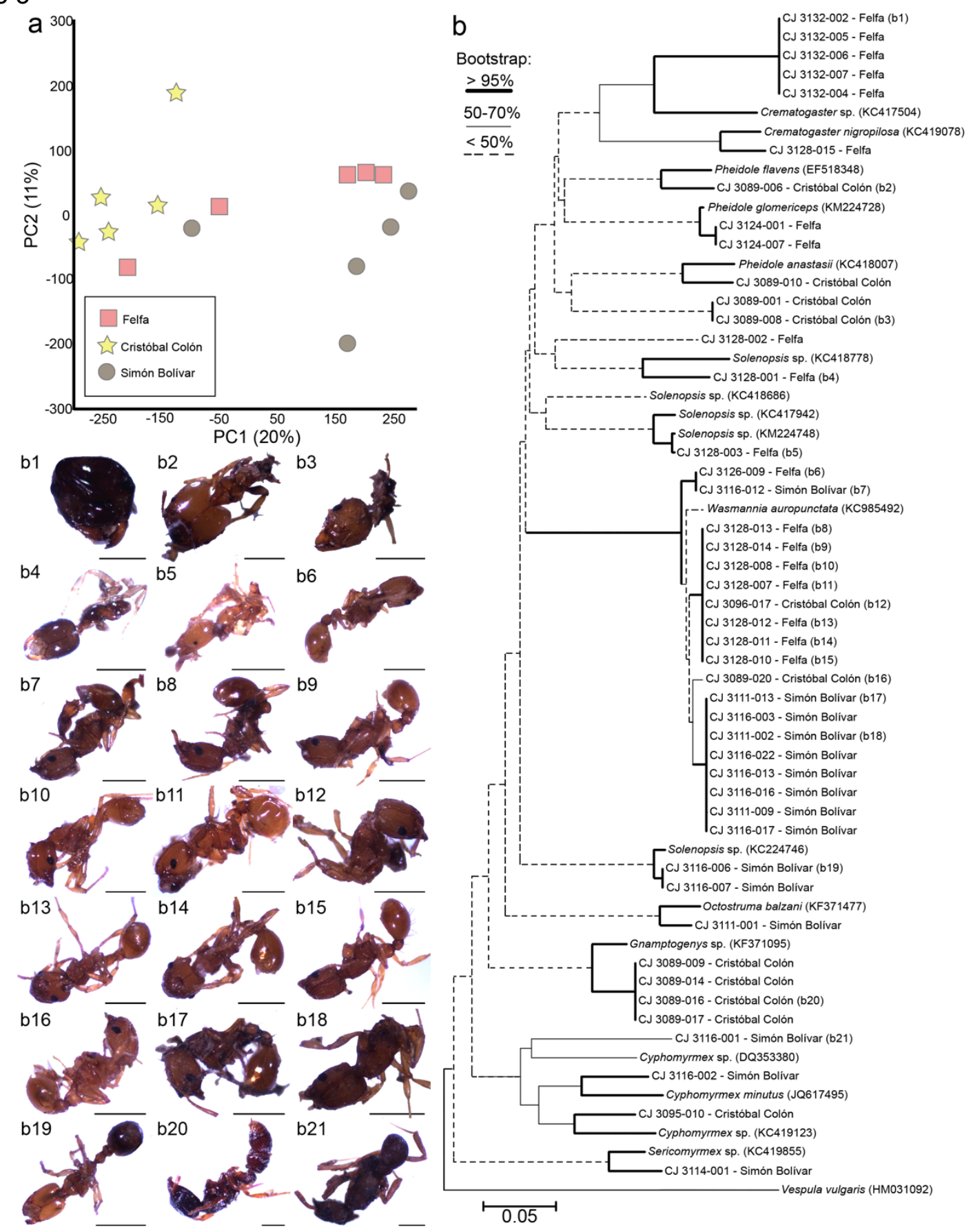

Figure 3. Identification and metabolomics of ants found in the stomachs of Little Devil frogs (Oophaga sylvatica). (a) Principal component analysis clustering of ant liquid chromatography mass spectrometry data colored by frog population. (b) A phylogenetic tree with nearest neighbor clustering shows relationships in cytochrome oxidase 1 sequence between ants isolated from 0 . sylvatica stomachs compared to other known ants. Ants are numbered by the four-digit frog specimen identifier followed by a three-digit number assigned to the arthropods in the order they were isolated from a single stomach. The frog population each ant was isolated from is listed beside each identifier. Genbank IDs of known ants are shown after the species name. The common wasp (Vespula vulgaris) was used as an outgroup. (b1-21) Photos of some specimen are shown, with varying degrees of being intact or partially digested. Scale bar 849 is $5 \mathrm{~mm}$. 
Figure 4
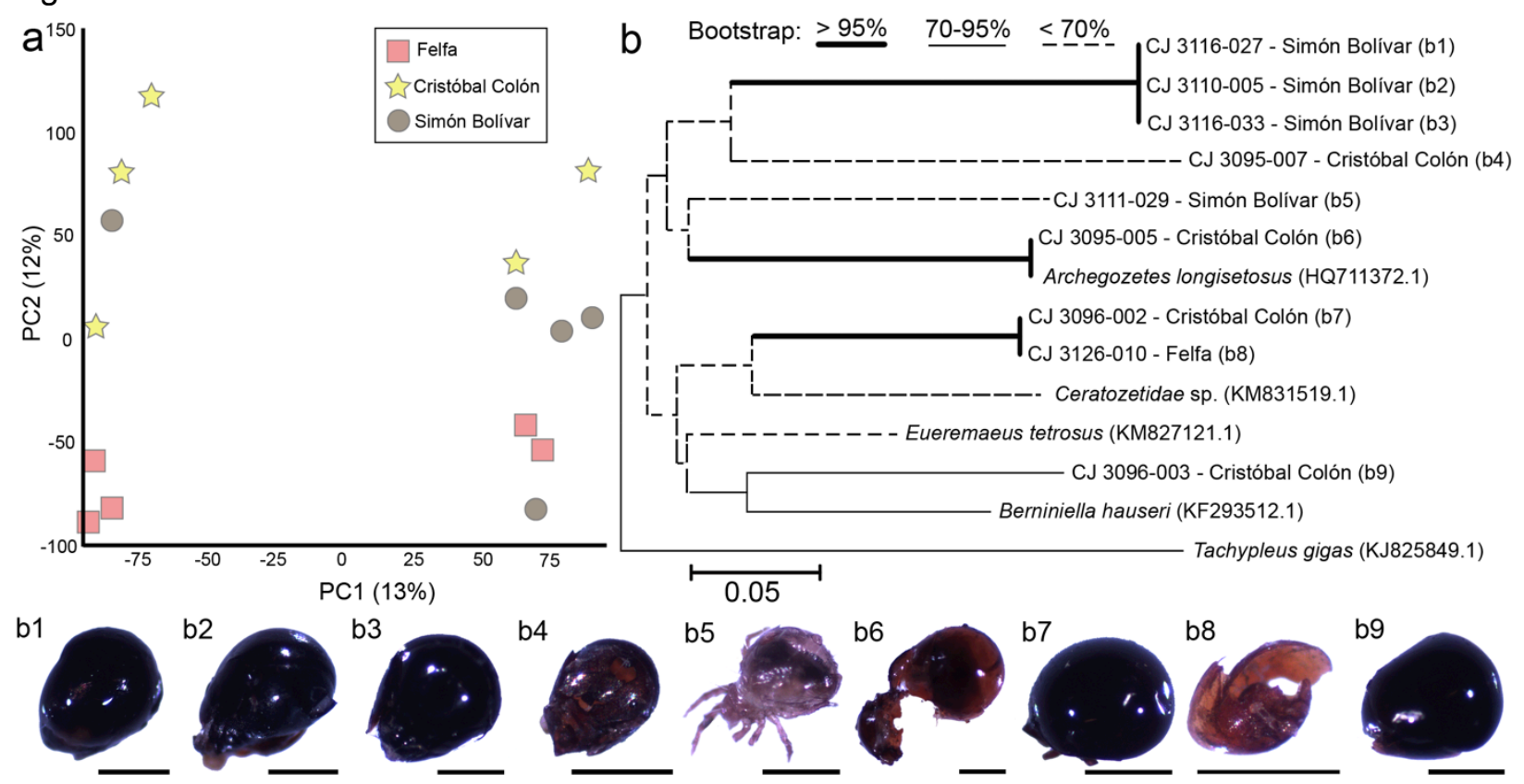

Figure 4. Identification of mites found in the stomachs of Little Devil frogs (Oophaga sylvatica). (a) Principal component analysis clustering of mite liquid chromatography mass spectrometry data colored by frog population. (b) A phylogenetic tree with nearest neighbor clustering shows relationships in cytochrome oxidase 1 sequence between mites isolated from $O$. sylvatica stomachs compared to other mites. Isolated mites are numbered by the four-digit frog identifier followed by a three-digit number assigned to the arthropods in the order they were isolated from a single frog stomach. The frog population each mite was isolated from is listed beside each identifier. Genbank IDs of known mites are shown after the species name. A horseshoe crab (Tachypleus gigas) was used as an outgroup. (b1-9) Photos of each specimen are shown, with varying degrees of being intact or partially digested. Scale bar is $5 \mathrm{~mm}$. 
Figure 5

a
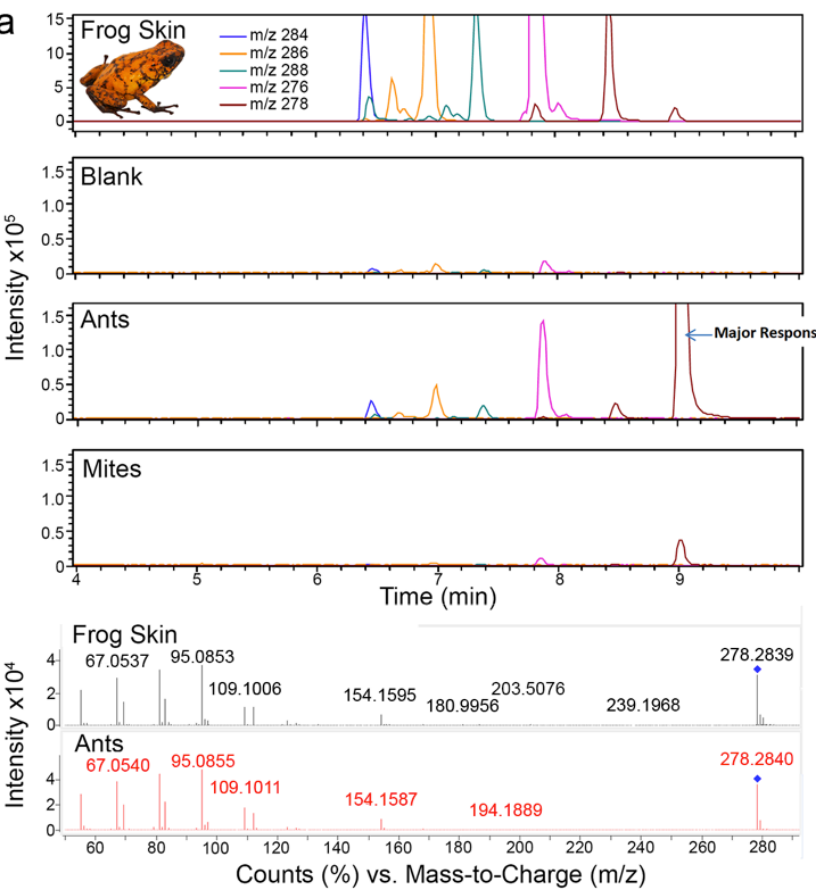

b
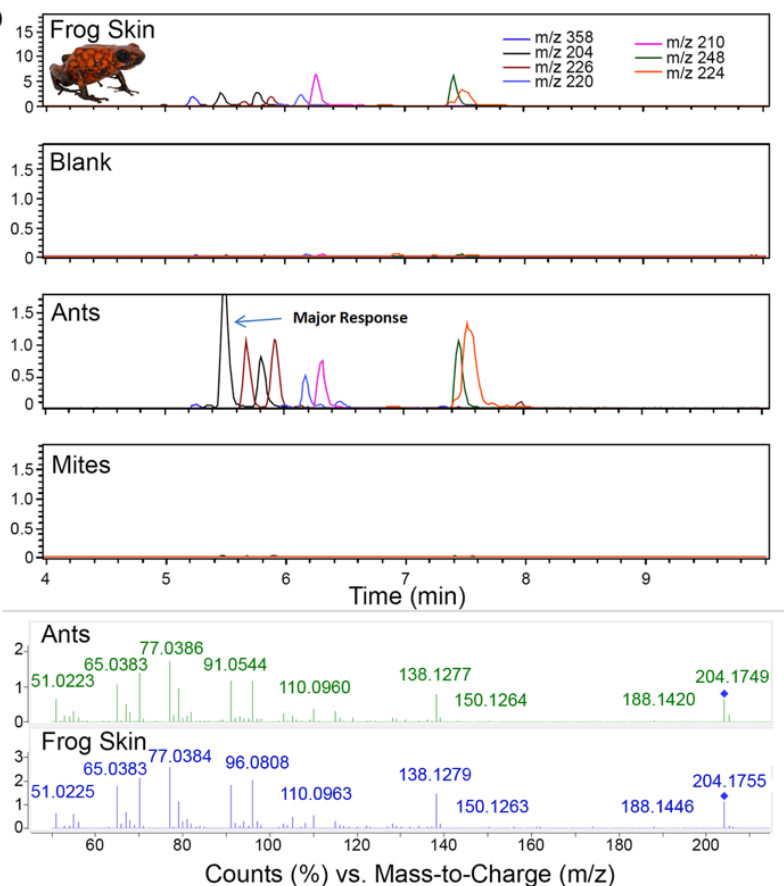

863

Figure 5. Identification of ants as a dietary source of Lehmizidine $277 \mathrm{~A}$ and 5,8-disubstituted indolizidine 203A in the Little Devil frog (Oophaga sylvatica). Liquid chromatography mass spectrometry (LCMS) was used to analyze alkaloids from $O$. sylvatica skin samples and the ants and mites found in those same frogs' stomachs. Top: Abundant alkaloids in the frogs were selected for extracted ion chromatogram analysis. Each compound is represented as a different color and mass-tocharge $(\mathrm{m} / \mathrm{z})$ ratios are listed at the top of each panel. In both comparisons from two different frogs, a major alkaloid response was detected in the ant sample that was similar to a response found in the frog skin sample. Bottom: Tandem mass spectrometry fragmentation patterns via $15 \mathrm{eV}$ product ion mass spectra shows a close match between the compounds found in the frogs and the ants. (a) A similar response of $\mathrm{m} / \mathrm{z} 278$ was found in a Cristóbal Colón frog skin sample and the corresponding ant sample. Comparison with the GCMS data from this frog suggests the identity of this shared alkaloid is lehmizidine 277A. (b) A similar response of $\mathrm{m} / \mathrm{z} 204$ was found in a Felfa frog skin sample and the corresponding ant sample. Comparison with the GCMS data from this frog suggests the identity of this shared alkaloid is 5,8-disubstituted indolizidine 203A. 
Figure 6
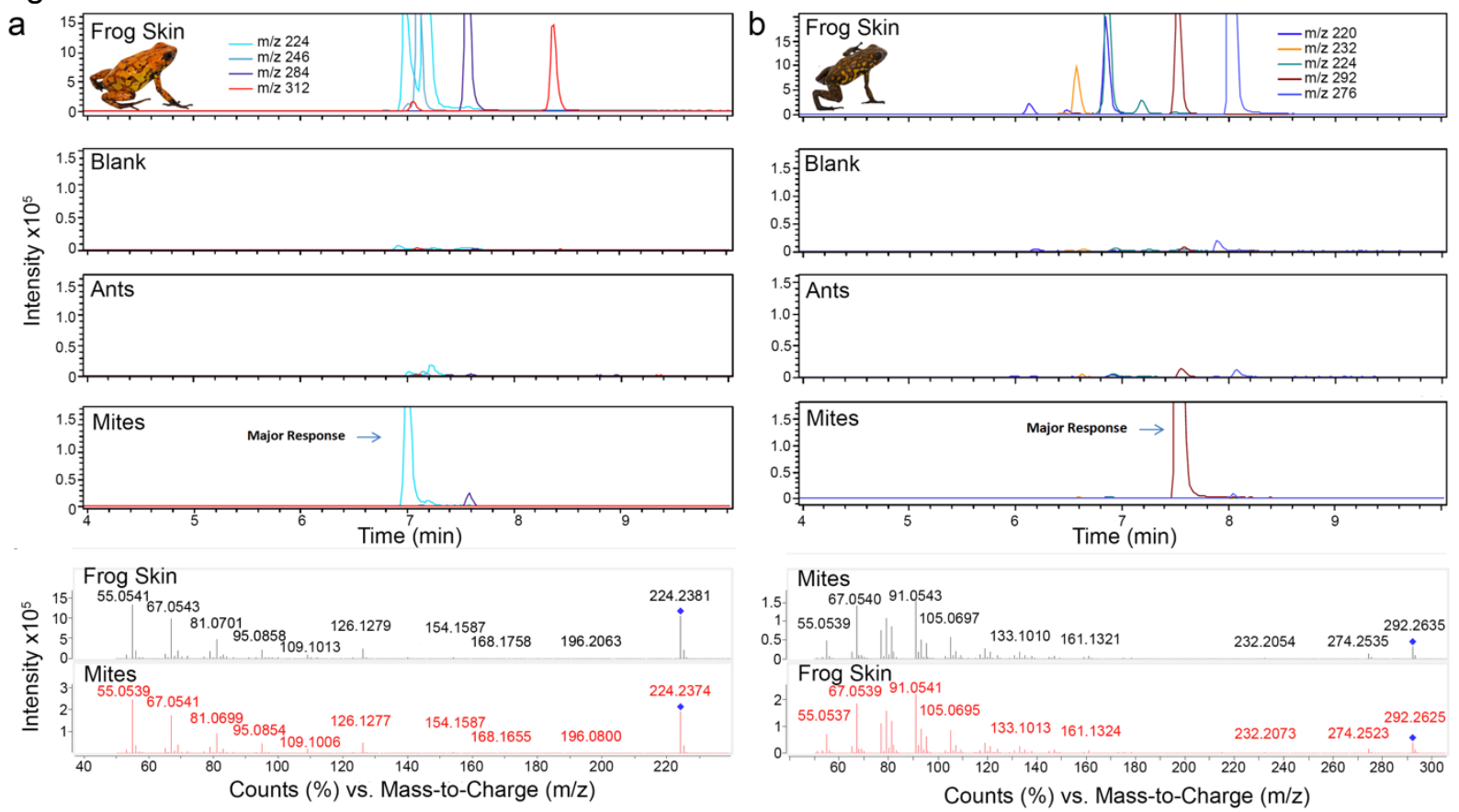

Figure 6. Identification of mites as dietary source of 3,5-disubstituted indolizidine 223AB and an unknown alkaloid in the Little Devil frog (Oophaga sylvatica). Liquid chromatography mass spectrometry (LCMS) was used to analyze alkaloids from O. sylvatica frog skin samples and the ants and mites found in those same frogs' stomachs. Top: Abundant alkaloids in the frogs were selected for extracted ion chromatogram analysis. Each compound is represented as a different color and mass-tocharge $(\mathrm{m} / \mathrm{z})$ ratios are listed in the top of each frog panel. In both comparisons from two different frogs, a major alkaloid response was detected in the mite sample that was similar to a response found in the frog skin sample. Bottom: Tandem mass spectrometry fragmentation patterns via $15 \mathrm{eV}$ product ion mass spectra shows a close match between the compounds found in the frogs and the mites. (a) A similar response of $\mathrm{m} / \mathrm{z} 224$ was found in a Cristóbal Colón frog skin sample and the corresponding mite sample. Comparison with the GCMS data from this frog suggests the identity of this shared alkaloid is 3,5disubstituted indolizidine 223AB. (b) A similar response of $\mathrm{m} / \mathrm{z} 292$ was found in a Simón Bolívar frog skin sample and the corresponding mite sample. Identification of this alkaloid is not possible, as it was not observed in GCMS data for this frog. 
Diet
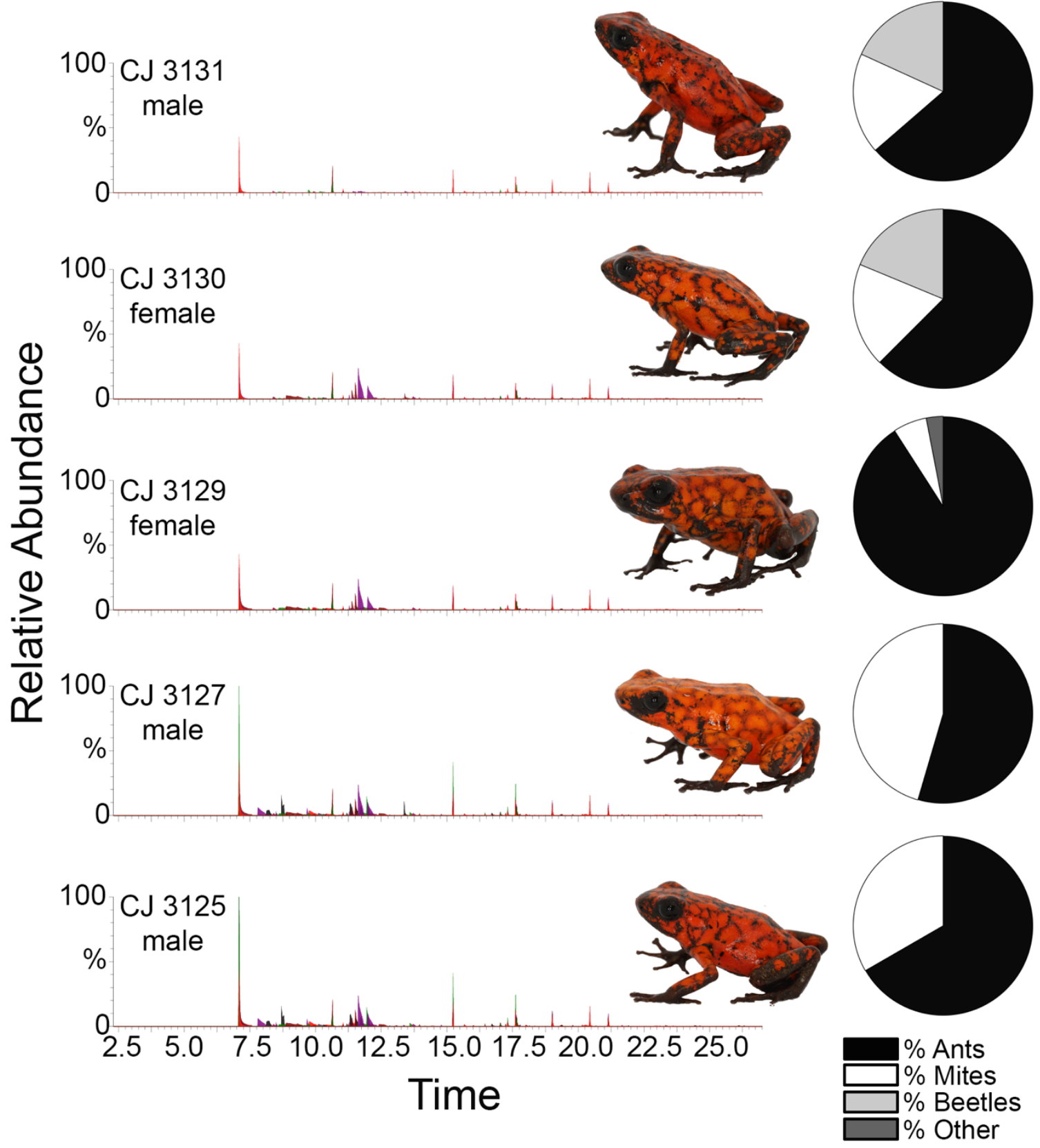

Supplementary Figure 1. Individual variation in alkaloid profiles and morphology in the Little Devil frog (Oophaga sylvatica) Felfa population. (a) Skin alkaloid toxin profiles assayed by gas chromatography mass spectrometry (GCMS) show little individual variation in chemical defenses where each peak is a chemical and peak amplitude represents abundance. A picture of each individual is displayed in the right of each chromatogram. The pie chart on the right shows each frog's stomach content composition of percent ants (black), mites (white), beetles (light grey) or other arthropods (dark 908 grey) by number. 


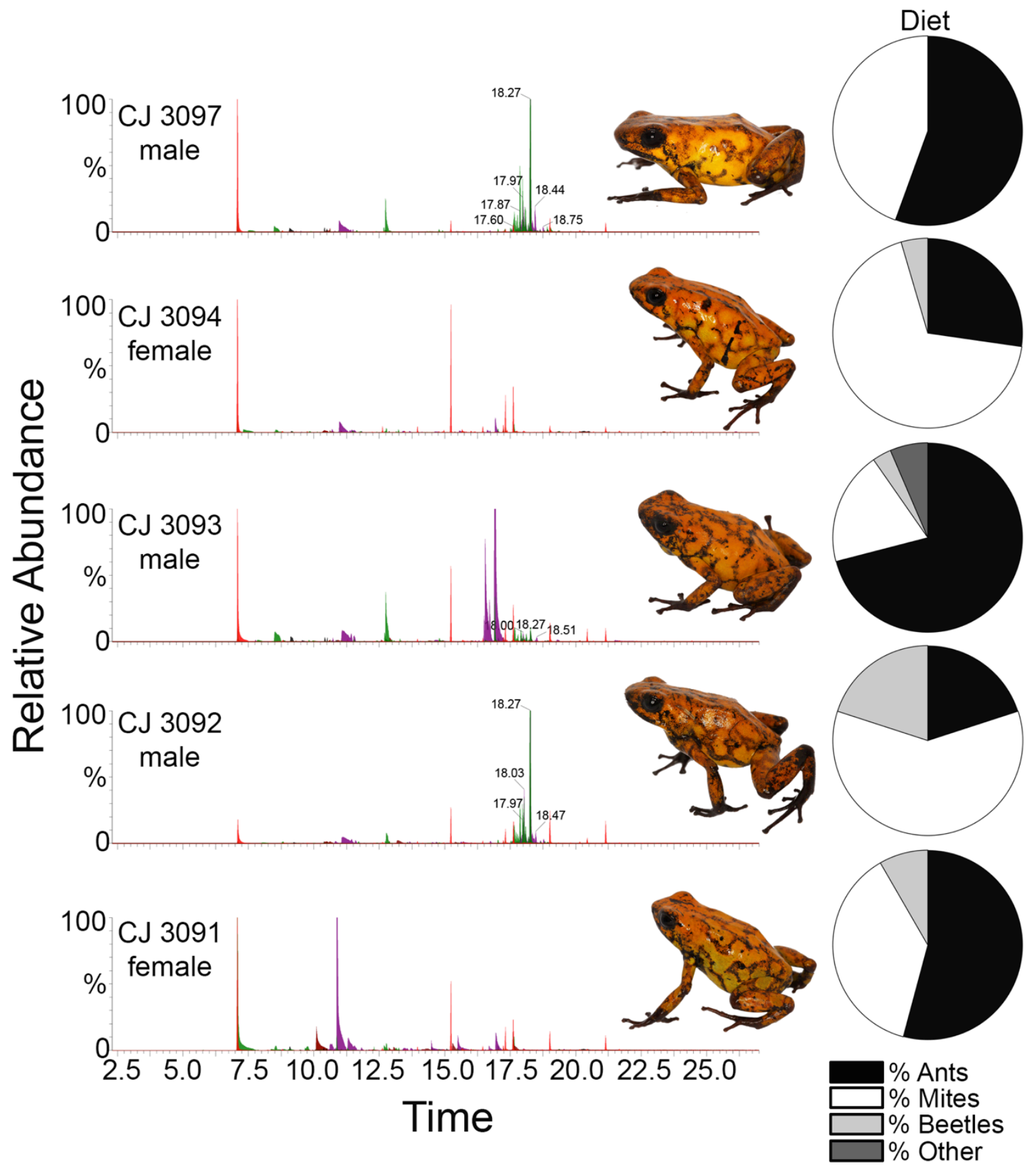

Supplementary Figure 2. Individual variation in alkaloid profiles and morphology in the Little Devil frog (Oophaga sylvatica) Cristóbal Colón population. (a) Skin alkaloid toxin profiles assayed by gas chromatography mass spectrometry (GCMS) show individual variation in chemical defenses where each peak is a chemical and peak amplitude represents abundance. A picture of each individual is displayed in the right of each chromatogram. The pie chart on the right shows each frog's stomach content composition of percent ants (black), mites (white), beetles (light grey) or other arthropods (dark grey) by 


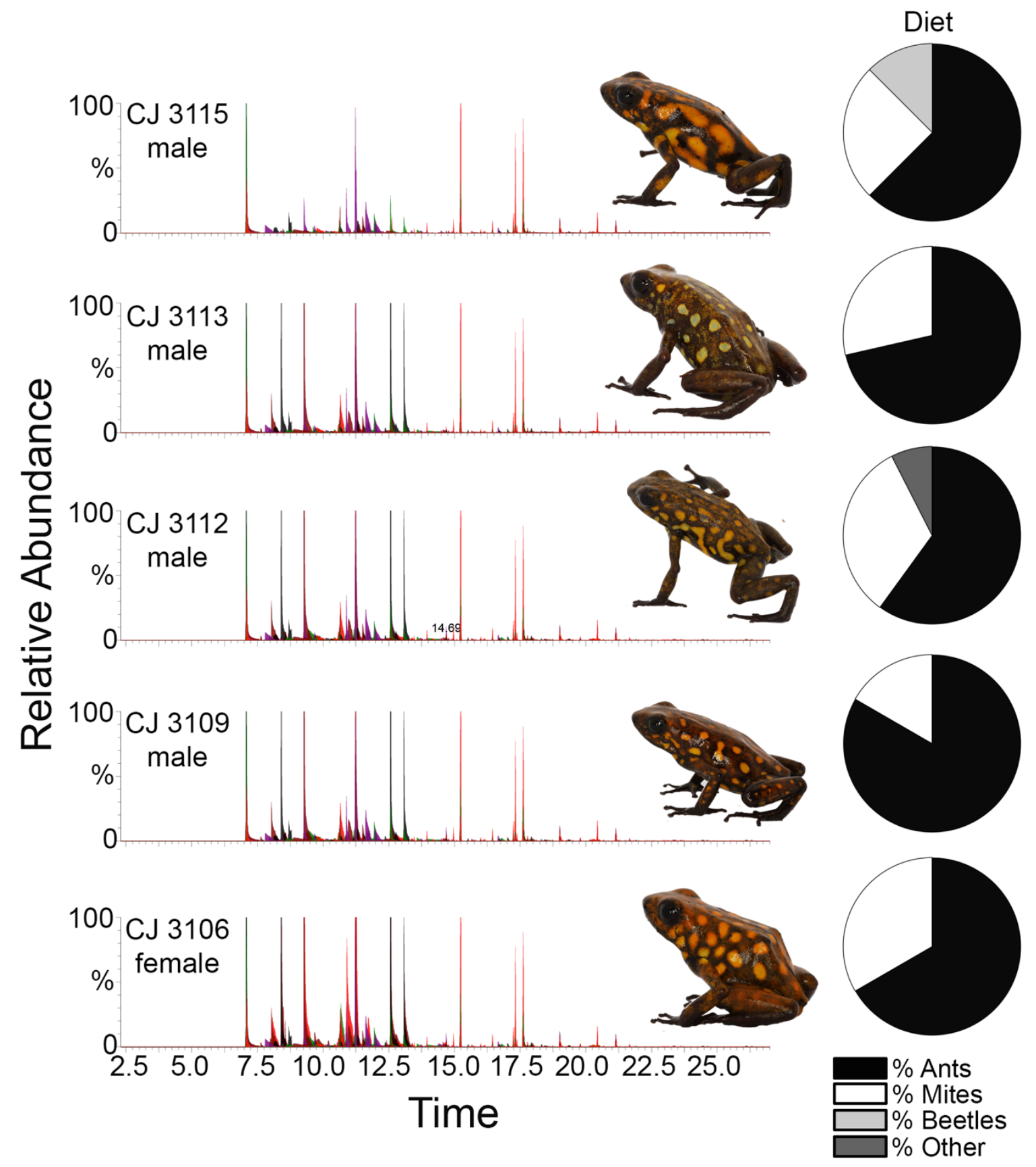

Supplementary Figure 3. Individual variation in alkaloid profiles and morphology in the Little Devil frog (Oophaga sylvatica) Simón Bolívar population. (a) Skin alkaloid toxin profiles assayed by gas chromatography mass spectrometry (GCMS) show little individual variation in chemical defenses where each peak is a chemical and peak amplitude represents abundance. A picture of each individual is displayed in the right of each chromatogram. The pie chart on the right shows each frog's stomach content composition of percent ants (black), mites (white), beetles (light grey) or other arthropods (dark grey) by number. 
bioRxiv preprint doi: https://doi.org/10.1101/031849; this version posted November 15,2015 . The copyright holder for this preprint (which was not certified by peer review) is the author/funder, who has granted bioRxiv a license to display the preprint in perpetuity. It is made available under aCC-BY-ND 4.0 International license.

\section{Supplementary Figure 4}

a

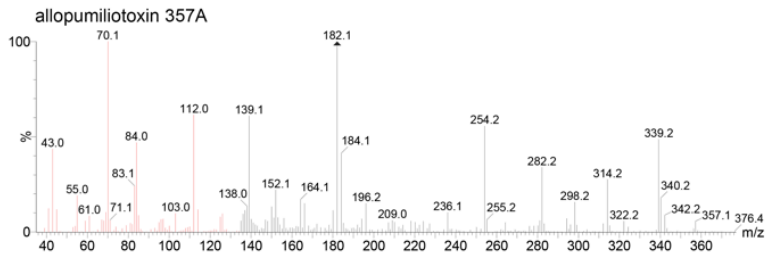

C

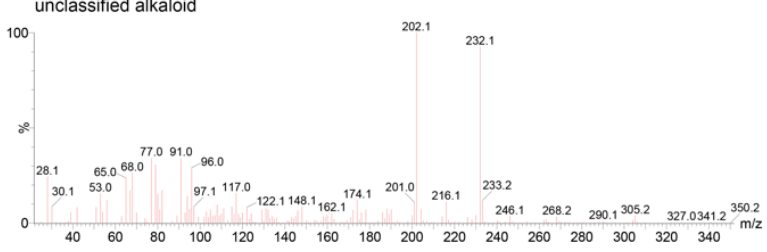

e

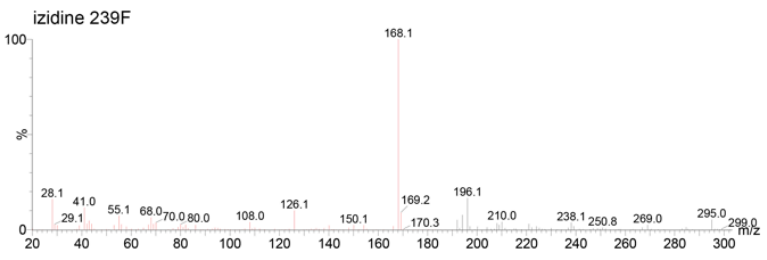

b izidine 211P

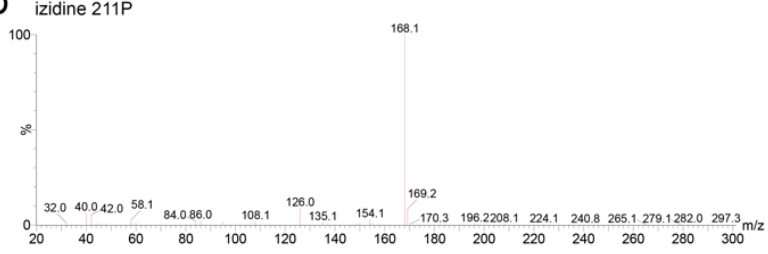

d unclassified alkaloid

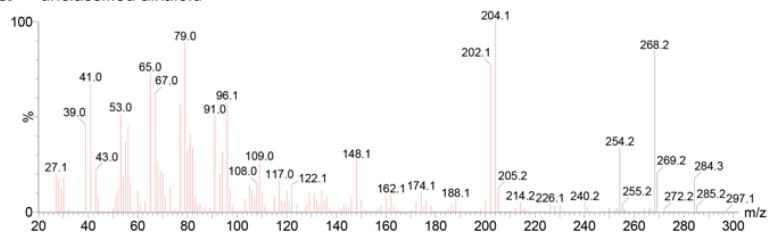

f trans-2-hexyl-5-heptyl-pyrrolidine (253l)

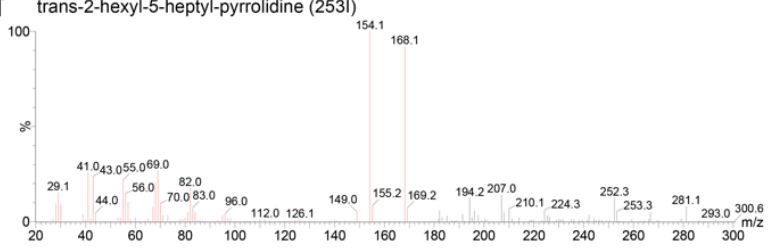


bioRxiv preprint doi: https://doi.org/10.1101/031849; this version posted November 15,2015 . The copyright holder for this preprint (which was not certified by peer review) is the author/funder, who has granted bioRxiv a license to display the preprint in perpetuity. It is made available under aCC-BY-ND 4.0 International license.

Supplementary Figure 5

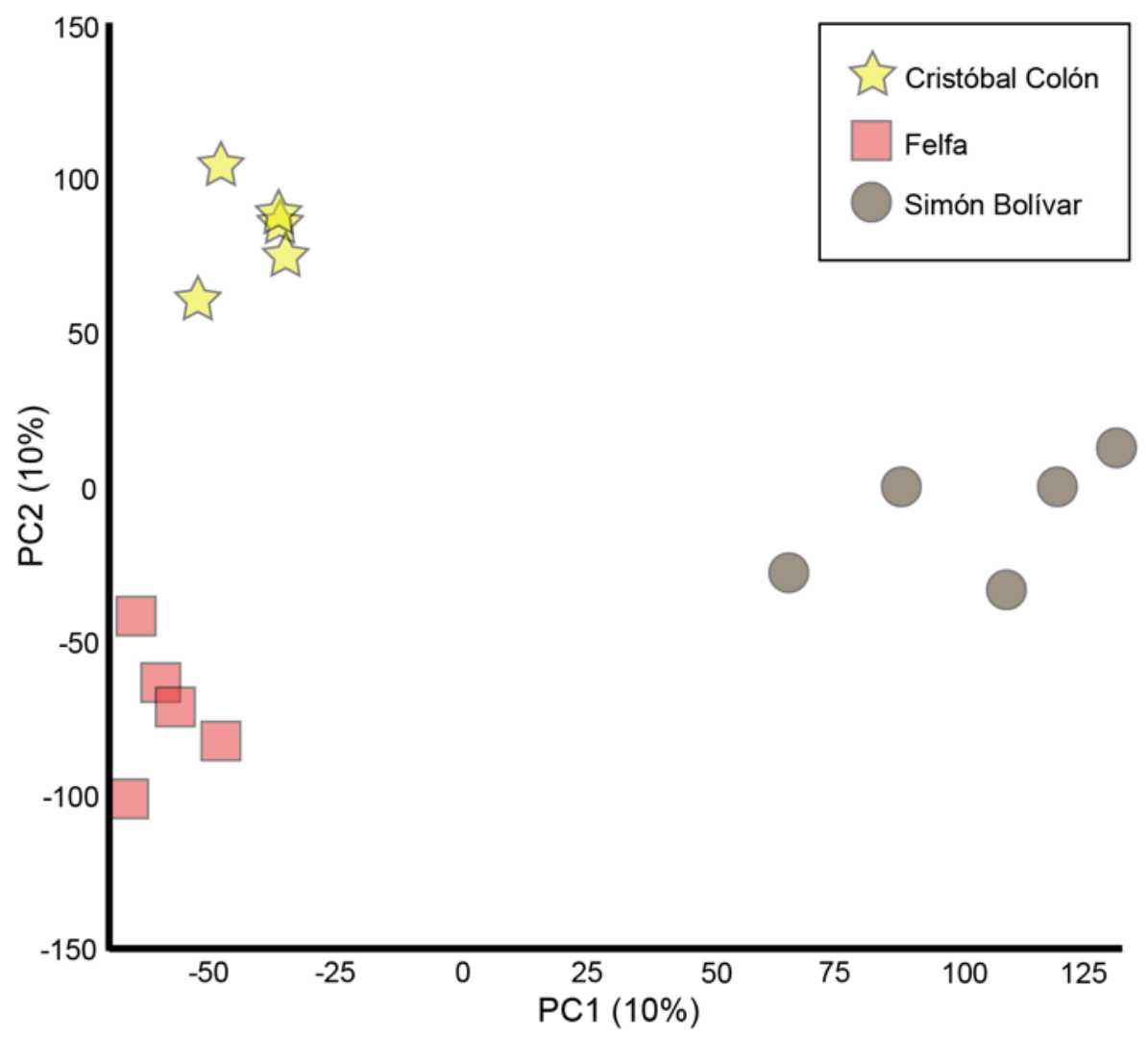
chromatography mass spectrometry analysis. 
Supplementary Figure 6
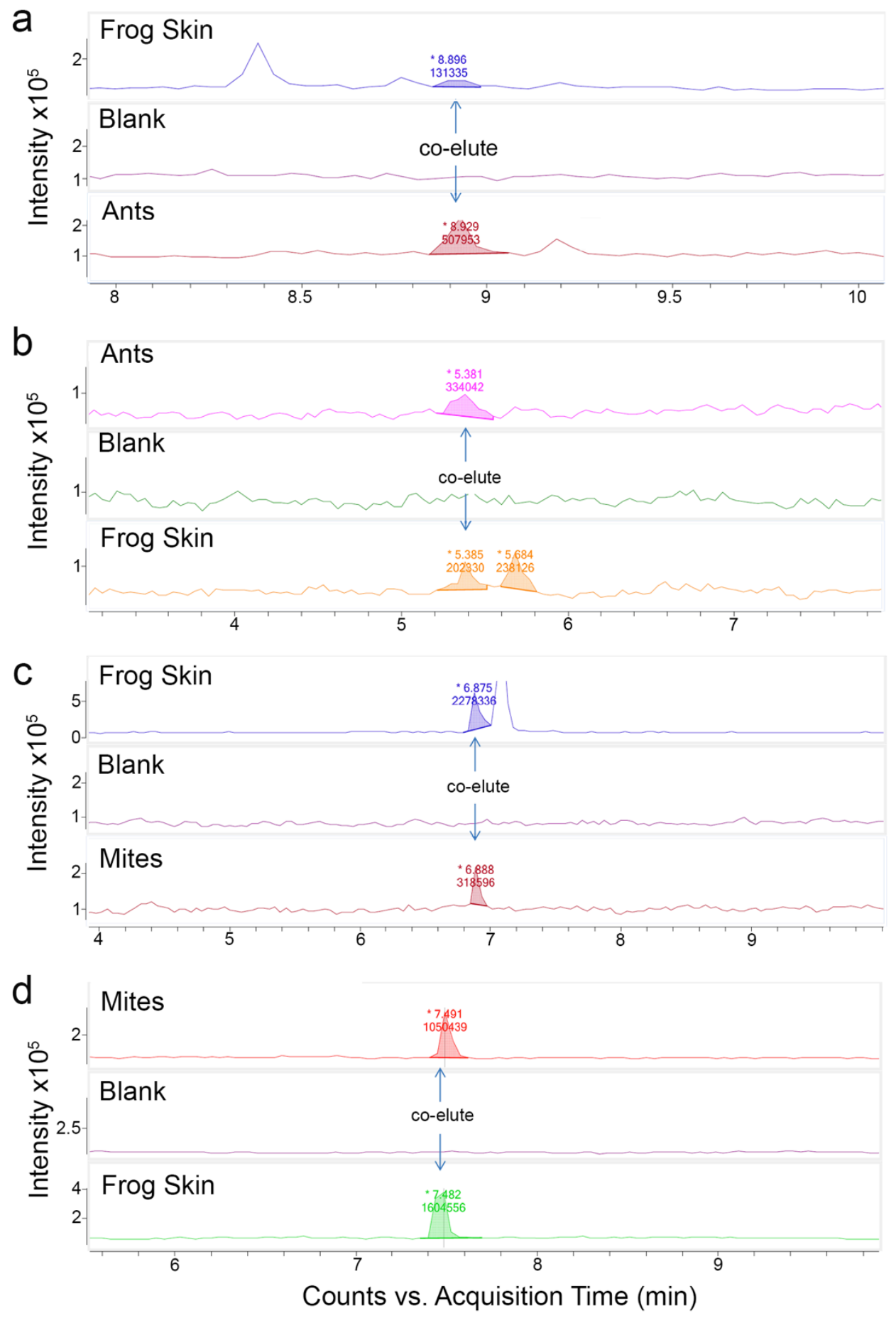

Counts vs. Acquisition Time (min)

941 Supplementary Figure 6. $(\mathrm{M}+\mathrm{H})^{+}$product scans to compare retention times of frog and arthropod compounds and confirm co-elution. A methanol blank sample was run in between each frog skin and arthropod sample to ensure the matching compound was not due to carryover. (a) The major common response of the $\mathrm{m} / \mathrm{z} 278$ compound in the frog skin and ant sample (Figure 5a). (b) The major common response of the $\mathrm{m} / \mathrm{z} 204$ compound in the frog skin and ant sample (Figure $5 \mathrm{~b}$ ). (c) The major common response of the $\mathrm{m} / \mathrm{z} 224$ compound in the frog skin and mites sample (Figure 6a). (d) The major common response of the $\mathrm{m} / \mathrm{z} 292$ compound in the frog skin and mites sample (Figure 6b). 


\section{Supplementary Tables}

Supplementary Table 1. Ant identification using cytochrome oxidase 1.

\begin{tabular}{|c|c|c|c|c|c|c|c|}
\hline $\begin{array}{c}\text { Sub-Family } \\
\text { (Tribe) }\end{array}$ & Sample ID & $\begin{array}{l}\text { GenBank } \\
\text { Accession }\end{array}$ & $\begin{array}{c}\text { Frog } \\
\text { Population } \\
\end{array}$ & $\begin{array}{l}\text { BLASTn Species } \\
\text { (closest match) }\end{array}$ & $\begin{array}{c}\text { GenBank } \\
\text { (closest match) }\end{array}$ & Similarity & $\begin{array}{c}E \\
\text { Value }\end{array}$ \\
\hline $\begin{array}{l}\text { Myrmicinae } \\
\text { (Attini) }\end{array}$ & CJ 3111-001 & KU128492 & Simón Bolívar & Octostruma sp. & KF371477 & $94 \%$ & 0 \\
\hline $\begin{array}{l}\text { Myrmicinae } \\
\text { (Attini) }\end{array}$ & CJ 3111-002 & KU128470 & Simón Bolívar & $\begin{array}{l}\text { Wasmannia } \\
\text { auropunctata }\end{array}$ & KC985492 & $97 \%$ & 0 \\
\hline $\begin{array}{l}\text { Myrmicinae } \\
\text { (Attini) }\end{array}$ & CJ 3111-009 & KU128471 & Simón Bolívar & $\begin{array}{l}\text { Wasmannia } \\
\text { auropunctata }\end{array}$ & KC985492 & $96 \%$ & 0 \\
\hline $\begin{array}{l}\text { Myrmicinae } \\
\text { (Attini) }\end{array}$ & CJ 3111-013 & KU128473 & Simón Bolívar & $\begin{array}{l}\text { Wasmannia } \\
\text { auropunctata }\end{array}$ & KC985492 & $97 \%$ & 0 \\
\hline $\begin{array}{l}\text { Myrmicinae } \\
\text { (Attini) }\end{array}$ & CJ 3114-001 & KU128490 & Simón Bolívar & Sericomyrmex sp. & KC419855 & $94 \%$ & 0 \\
\hline $\begin{array}{l}\text { Myrmicinae } \\
\text { (Attini) }\end{array}$ & CJ 3116-001 & KU128487 & Simón Bolívar & Cyphomyrmex sp. & DQ353380 & $86 \%$ & 0 \\
\hline $\begin{array}{l}\text { Myrmicinae } \\
\text { (Attini) }\end{array}$ & CJ 3116-002 & KU128488 & Simón Bolívar & $\begin{array}{c}\text { Cyphomyrmex } \\
\text { minutus }\end{array}$ & JQ617495 & $91 \%$ & 0 \\
\hline $\begin{array}{l}\text { Myrmicinae } \\
\text { (Attini) }\end{array}$ & CJ 3116-003 & KU128474 & Simón Bolívar & $\begin{array}{l}\text { Wasmannia } \\
\text { auropunctata }\end{array}$ & KC985492 & $97 \%$ & 0 \\
\hline $\begin{array}{c}\text { Myrmicinae } \\
\text { (Solenopsidini) }\end{array}$ & CJ 3116-006 & KU128483 & Simón Bolívar & Solenopsis sp. & KM224746 & $98 \%$ & 0 \\
\hline $\begin{array}{c}\text { Myrmicinae } \\
\text { (Solenopsidini) }\end{array}$ & CJ 3116-007 & KU128484 & Simón Bolívar & Solenopsis sp. & KM224746 & $98 \%$ & 0 \\
\hline $\begin{array}{l}\text { Myrmicinae } \\
\text { (Attini) }\end{array}$ & CJ 3116-012 & KU128478 & Simón Bolívar & $\begin{array}{l}\text { Wasmannia } \\
\text { auropunctata }\end{array}$ & KC985492 & $97 \%$ & 0 \\
\hline $\begin{array}{l}\text { Myrmicinae } \\
\text { (Attini) }\end{array}$ & CJ 3116-013 & KU128468 & Simón Bolívar & $\begin{array}{l}\text { Wasmannia } \\
\text { auropunctata }\end{array}$ & KC985492 & $97 \%$ & 0 \\
\hline $\begin{array}{l}\text { Myrmicinae } \\
\text { (Attini) }\end{array}$ & CJ 3116-016 & KU128472 & Simón Bolívar & $\begin{array}{l}\text { Wasmannia } \\
\text { auropunctata }\end{array}$ & KC985492 & $97 \%$ & 0 \\
\hline $\begin{array}{l}\text { Myrmicinae } \\
\text { (Attini) }\end{array}$ & CJ 3116-017 & KU128475 & Simón Bolívar & $\begin{array}{l}\text { Wasmannia } \\
\text { auropunctata }\end{array}$ & KC985492 & $97 \%$ & 0 \\
\hline $\begin{array}{l}\text { Myrmicinae } \\
\text { (Attini) }\end{array}$ & CJ 3116-022 & KU128469 & Simón Bolívar & $\begin{array}{l}\text { Wasmannia } \\
\text { auropunctata }\end{array}$ & KC985492 & $97 \%$ & 0 \\
\hline $\begin{array}{c}\text { Myrmicinae } \\
\text { (Solenopsidini) }\end{array}$ & CJ 3089-001 & KU128458 & $\begin{array}{l}\text { Cristóbal } \\
\text { Colón }\end{array}$ & Solenopsis sp. & KC418686 & $85 \%$ & 0 \\
\hline $\begin{array}{l}\text { Myrmicinae } \\
\text { (Attini) }\end{array}$ & CJ 3089-006 & KU128496 & $\begin{array}{l}\text { Cristóbal } \\
\text { Colón }\end{array}$ & Pheidole sp. & EF518348 & $93 \%$ & 0 \\
\hline $\begin{array}{l}\text { Myrmicinae } \\
\text { (Attini) }\end{array}$ & CJ 3089-008 & KU128459 & $\begin{array}{l}\text { Cristóbal } \\
\text { Colón }\end{array}$ & Solenopsis sp. & KC418686 & $85 \%$ & 0 \\
\hline $\begin{array}{l}\text { Ectatomminae } \\
\text { (Ectatommini) }\end{array}$ & CJ 3089-009 & KU128479 & $\begin{array}{l}\text { Cristóbal } \\
\text { Colón }\end{array}$ & Gnamptogenys sp. & KF371095 & $95 \%$ & 0 \\
\hline $\begin{array}{l}\text { Myrmicinae } \\
\text { (Attini) }\end{array}$ & CJ 3089-010 & KU128493 & $\begin{array}{l}\text { Cristóbal } \\
\text { Colón }\end{array}$ & Pheidole sp. & KC418007 & $93 \%$ & 0 \\
\hline $\begin{array}{l}\text { Ectatomminae } \\
\text { (Ectatommini) }\end{array}$ & CJ 3089-014 & KU128480 & $\begin{array}{l}\text { Cristóbal } \\
\text { Colón }\end{array}$ & Gnamptogenys sp. & KF371095 & $95 \%$ & 0 \\
\hline $\begin{array}{l}\text { Ectatomminae } \\
\text { (Ectatommini) }\end{array}$ & CJ 3089-016 & KU128481 & $\begin{array}{l}\text { Cristóbal } \\
\text { Colón }\end{array}$ & Gnamptogenys sp. & KF371095 & $95 \%$ & 0 \\
\hline $\begin{array}{l}\text { Ectatomminae } \\
\text { (Ectatommini) }\end{array}$ & CJ 3089-017 & KU128482 & $\begin{array}{l}\text { Cristóbal } \\
\text { Colón }\end{array}$ & Gnamptogenys sp. & KF371095 & $95 \%$ & 0 \\
\hline $\begin{array}{l}\text { Myrmicinae } \\
\text { (Attini) }\end{array}$ & CJ 3089-020 & KU128476 & $\begin{array}{l}\text { Cristóbal } \\
\text { Colón }\end{array}$ & $\begin{array}{l}\text { Wasmannia } \\
\text { auropunctata }\end{array}$ & KC985492 & $97 \%$ & 0 \\
\hline $\begin{array}{l}\text { Myrmicinae } \\
\text { (Attini) }\end{array}$ & CJ 3095-010 & KU128489 & $\begin{array}{l}\text { Cristóbal } \\
\text { Colón }\end{array}$ & Cyphomyrmex sp. & KC419123 & $91 \%$ & 0 \\
\hline $\begin{array}{l}\text { Myrmicinae } \\
\text { (Attini) }\end{array}$ & CJ 3096-017 & KU128463 & $\begin{array}{l}\text { Cristóbal } \\
\text { Colón }\end{array}$ & $\begin{array}{l}\text { Wasmannia } \\
\text { auropunctata }\end{array}$ & KC985492 & $97 \%$ & 0 \\
\hline $\begin{array}{l}\text { Myrmicinae } \\
\text { (Attini) }\end{array}$ & CJ 3124-001 & KU128494 & Felfa & $\begin{array}{c}\text { Pheidole } \\
\text { glomericeps }\end{array}$ & KM224728 & $98 \%$ & 0 \\
\hline $\begin{array}{l}\text { Myrmicinae } \\
\text { (Attini) }\end{array}$ & CJ 3124-007 & KU128495 & Felfa & $\begin{array}{c}\text { Pheidole } \\
\text { glomericeps }\end{array}$ & KM224728 & $98 \%$ & 0 \\
\hline $\begin{array}{l}\text { Myrmicinae } \\
\text { (Attini) }\end{array}$ & CJ 3126-009 & KU128477 & Felfa & $\begin{array}{l}\text { Wasmannia } \\
\text { auropunctata }\end{array}$ & KC985492 & $96 \%$ & 0 \\
\hline $\begin{array}{c}\text { Myrmicinae } \\
\text { (Solenopsidini) }\end{array}$ & CJ 3128-001 & KU128485 & Felfa & Solenopsis sp. & KC418778 & $90 \%$ & 0 \\
\hline $\begin{array}{c}\text { Myrmicinae } \\
\text { (Solenopsidini) }\end{array}$ & CJ 3128-002 & KU128486 & Felfa & Solenopsis sp. & KC417942 & $85 \%$ & 0 \\
\hline $\begin{array}{l}\text { Myrmicinae } \\
\text { (Solenopsidini) }\end{array}$ & CJ 3128-003 & KU128491 & Felfa & Solenopsis sp. & KM224748 & $99 \%$ & 0 \\
\hline
\end{tabular}


bioRxiv preprint doi: https://doi.org/10.1101/031849; this version posted November 15,2015 . The copyright holder for this preprint (which was not certified by peer review) is the author/funder, who has granted bioRxiv a license to display the preprint in perpetuity. It is made available under aCC-BY-ND 4.0 International license.

\begin{tabular}{|c|c|c|c|c|c|c|c|}
\hline $\begin{array}{l}\text { Myrmicinae } \\
\text { (Attini) }\end{array}$ & CJ 3128-007 & KU128464 & Felfa & $\begin{array}{l}\text { Wasmannia } \\
\text { auropunctata }\end{array}$ & KC985492 & $97 \%$ & 0 \\
\hline $\begin{array}{l}\text { Myrmicinae } \\
\text { (Attini) }\end{array}$ & CJ 3128-008 & KU128467 & Felfa & $\begin{array}{l}\text { Wasmannia } \\
\text { auropunctata }\end{array}$ & KC985492 & $96 \%$ & 0 \\
\hline $\begin{array}{l}\text { Myrmicinae } \\
\text { (Attini) }\end{array}$ & CJ 3128-010 & KU128460 & Felfa & $\begin{array}{l}\text { Wasmannia } \\
\text { auropunctata }\end{array}$ & KC985492 & $97 \%$ & 0 \\
\hline $\begin{array}{l}\text { Myrmicinae } \\
\text { (Attini) }\end{array}$ & CJ 3128-011 & KU128461 & Felfa & $\begin{array}{l}\text { Wasmannia } \\
\text { auropunctata }\end{array}$ & KC985492 & $97 \%$ & 0 \\
\hline $\begin{array}{l}\text { Myrmicinae } \\
\text { (Attini) }\end{array}$ & CJ 3128-012 & KU128462 & Felfa & $\begin{array}{l}\text { Wasmannia } \\
\text { auropunctata }\end{array}$ & KC985492 & $97 \%$ & 0 \\
\hline $\begin{array}{l}\text { Myrmicinae } \\
\text { (Attini) }\end{array}$ & CJ 3128-013 & KU128465 & Felfa & $\begin{array}{l}\text { Wasmannia } \\
\text { auropunctata }\end{array}$ & KC985492 & $97 \%$ & 0 \\
\hline $\begin{array}{l}\text { Myrmicinae } \\
\text { (Attini) }\end{array}$ & CJ 3128-014 & KU128466 & Felfa & $\begin{array}{l}\text { Wasmannia } \\
\text { auropunctata }\end{array}$ & KC985492 & $97 \%$ & 0 \\
\hline $\begin{array}{l}\text { Myrmicinae } \\
\text { (Crematogastri } \\
\text { ni) }\end{array}$ & CJ 3128-015 & KU128497 & Felfa & Crematogaster sp. & KC419078 & $94 \%$ & 0 \\
\hline $\begin{array}{l}\text { Myrmicinae } \\
\text { (Crematogastri } \\
\text { ni) }\end{array}$ & CJ 3132-002 & KU128456 & Felfa & Crematogaster sp. & KC417504 & $86 \%$ & 0 \\
\hline $\begin{array}{c}\text { Myrmicinae } \\
\text { (Crematogastri } \\
\text { ni) }\end{array}$ & CJ 3132-004 & KU128453 & Felfa & Crematogaster sp. & KC417504 & $86 \%$ & 0 \\
\hline $\begin{array}{l}\text { Myrmicinae } \\
\text { (Crematogastri } \\
\text { ni) }\end{array}$ & CJ 3132-005 & KU128457 & Felfa & Crematogaster sp. & KC417504 & $86 \%$ & 0 \\
\hline $\begin{array}{l}\text { Myrmicinae } \\
\text { (Crematogastri } \\
\text { ni) }\end{array}$ & CJ 3132-006 & KU128455 & Felfa & Crematogaster sp. & KC417504 & $86 \%$ & 0 \\
\hline $\begin{array}{c}\text { Myrmicinae } \\
\text { (Crematogastri } \\
\text { ni) }\end{array}$ & CJ 3132-007 & KU128454 & Felfa & Crematogaster $s p$ & KC417504 & $86 \%$ & 0 \\
\hline
\end{tabular}

Assigned taxonomic identity by Sub-Family (Tribe) is listed in the first column and is based on the similarity to other ant cytochrome oxidase 1 sequences in the NCBI nr database. The sample ID indicates the voucher specimen number of the frog from whose stomach the ant was isolated (first four digits) and a three digit number assigned to prey items in the order they were retrieved from the stomach contents. The GenBank Accession number for each sequence is listed in the third column. The population of the frog from which each ant was isolated is listed in the fourth column. The closest arthropod hit for each specimen and its GenBank accession number is listed along with the similarity (percent identity) between the specimen and the closest GenBank match. The E-value statistic for the match is listed in the last column. 
bioRxiv preprint doi: https://doi.org/10.1101/031849; this version posted November 15, 2015. The copyright holder for this preprint (which was not certified by peer review) is the author/funder, who has granted bioRxiv a license to display the preprint in perpetuity. It is made available under aCC-BY-ND 4.0 International license.

Supplementary Table 2. Mite identification using cytochrome oxidase 1.

\begin{tabular}{|c|c|c|c|c|c|c|c|}
\hline Order & $\begin{array}{c}\text { Sample } \\
\text { ID }\end{array}$ & $\begin{array}{l}\text { GenBank } \\
\text { Accession }\end{array}$ & $\begin{array}{c}\text { Frog } \\
\text { Population }\end{array}$ & $\begin{array}{l}\text { BLASTn Species } \\
\text { (closest match) }\end{array}$ & $\begin{array}{c}\text { GenBank } \\
\text { (closest match) }\end{array}$ & Similarity & $\begin{array}{c}E \\
\text { Value }\end{array}$ \\
\hline Oribatida & $\begin{array}{c}\text { CJ 3095- } \\
005\end{array}$ & KT947982 & $\begin{array}{l}\text { Cristóbal } \\
\text { Colón }\end{array}$ & Archegozetes longisetosus & HQ711372 & $99 \%$ & 0 \\
\hline Oribatida & $\begin{array}{c}\text { CJ 3095- } \\
007\end{array}$ & KT947987 & $\begin{array}{c}\text { Cristóbal } \\
\text { Colón }\end{array}$ & Ceratozetidae & KM831519 & $79 \%$ & $1 e-96$ \\
\hline Oribatida & $\begin{array}{c}\text { CJ 3096- } \\
002\end{array}$ & KT947981 & $\begin{array}{l}\text { Cristóbal } \\
\text { Colón }\end{array}$ & Sarcoptiformes & KM834143 & $84 \%$ & $4 e-119$ \\
\hline Oribatida & $\begin{array}{c}\text { CJ 3096- } \\
003\end{array}$ & KT947986 & $\begin{array}{l}\text { Cristóbal } \\
\text { Colón }\end{array}$ & Berniniella hauseri & KF293512 & $84 \%$ & 0 \\
\hline Oribatida & $\begin{array}{c}\text { CJ 3110- } \\
005\end{array}$ & KT947985 & Simón Bolívar & Oppiella nova & KM293453 & $78 \%$ & $2 e-117$ \\
\hline Oribatida & $\begin{array}{c}\text { CJ 3111- } \\
029\end{array}$ & KT947984 & Simón Bolívar & Eremaeidae & KM826715 & $79 \%$ & $2 e-114$ \\
\hline Oribatida & $\begin{array}{c}\text { CJ 3116- } \\
027\end{array}$ & KT947988 & Simón Bolívar & Eremaeidae & KM827121 & $79 \%$ & $7 e-113$ \\
\hline Oribatida & $\begin{array}{c}\text { CJ 3116- } \\
033\end{array}$ & KT947980 & Simón Bolívar & Oppiella nova & KF293453 & $79 \%$ & $4 e-120$ \\
\hline Oribatida & $\begin{array}{c}\text { CJ 3126- } \\
010\end{array}$ & KT947983 & Felfa & Eueremaeus tetrosus & KM839082 & $84 \%$ & $1 e-142$ \\
\hline
\end{tabular}

Assigned taxonomic identity by Order is listed in the first column and is based on the similarity to other mite cytochrome oxidase 1 sequences in the NCBI nr database. The sample ID indicates the voucher specimen number of the frog from whose stomach the mite was isolated (first four digits) and a three digit number assigned to prey items in the order they were retrieved from the stomach contents. The GenBank Accession number for each sequence is listed in the third column. The population of the frog from which each mite was isolated is listed in the fourth column. The closest arthropod hit for each specimen and its GenBank accession number is listed along with the similarity (percent identity) between the specimen and the closest GenBank match. The E-value statistic for the match is listed in the last column. 